\title{
Heavy Rainfall Episodes in the Eastern Northeast Brazil Linked to Large-Scale Ocean-Atmosphere Conditions in the Tropical Atlantic
}

\author{
Yves K. Kouadio, ${ }^{1,2}$ Jacques Servain,, ${ }^{2,3}$ Luiz A. T. Machado, ${ }^{4}$ and Carlos A. D. Lentini ${ }^{5}$ \\ ${ }^{1}$ Laboratoire de Physique de l'Atmosphère (LPA), UFR-SSMT, Université de Cocody, 22 BP 582, Abidjan 22, Cote D'Ivoire \\ ${ }^{2}$ Fundação Cearense de Meteorologia e Recursos Hídricos (FUNCEME), Avenida Rui Barbosa 1246, Aldeota, \\ 60115-221 Fortaleza, CE, Brazil \\ ${ }^{3}$ Institut de Recherche pour le Développement (IRD), UMR182-LOCEAN, Université de Paris VI, 4 Place Jussieu, 75252 Paris, France \\ ${ }^{4}$ Instituto Nacional de Pesquisas Espaciais (INPE), Centro de Previsão de Tempo e Estudos Climáticos (CPTEC), Rodovia Pres. Dutra, \\ km 40, 12630-000 Cachoeira Paulista, SP, Brazil \\ ${ }^{5}$ Grupo de Oceanografia Tropical (GOAT), Instituto de Fisica, Departamento de Fisica da Terra e do Meio Ambiente, \\ Universidade Federal da Bahia (UFBA), Travessa Barão de Jeremoabo, s/n, Campus Ondina, 40170-280 Salvador, BA, Brazil
}

Correspondence should be addressed to Jacques Servain, jacques.servain@gmail.com

Received 19 December 2011; Accepted 19 May 2012

Academic Editor: Hann-Ming Henry Juang

Copyright (๑) 2012 Yves K. Kouadio et al. This is an open access article distributed under the Creative Commons Attribution License, which permits unrestricted use, distribution, and reproduction in any medium, provided the original work is properly cited.

\begin{abstract}
Relationships between simultaneous occurrences of distinctive atmospheric easterly wave (EW) signatures that cross the southequatorial Atlantic, intense mesoscale convective systems (lifespan $>2$ hour) that propagate westward over the western southequatorial Atlantic, and subsequent strong rainfall episodes (anomaly $>10 \mathrm{~mm} \cdot$ day $^{-1}$ ) that occur in eastern Northeast Brazil (ENEB) are investigated. Using a simple diagnostic analysis, twelve cases with EW lifespan ranging between 3 and 8 days and a mean velocity of $8 \mathrm{~m} \cdot \mathrm{s}^{-1}$ were selected and documented during each rainy season of 2004, 2005, and 2006. These cases, which represent $50 \%$ of the total number of strong rainfall episodes and $60 \%$ of the rainfall amount over the ENEB, were concomitant with an acceleration of the trade winds over the south-equatorial Atlantic, an excess of moisture transported westward from Africa to America, and a strengthening of the convective activity in the oceanic region close to Brazil. Most of these episodes occurred during positive sea surface temperature anomaly patterns over the entire south-equatorial Atlantic and low-frequency warm conditions within the oceanic mixing layer. A real-time monitoring and the simulation of this ocean-atmosphere relationship could help in forecasting such dramatic rainfall events.
\end{abstract}

\section{Introduction}

The Northeast region of Brazil (NEB) is located between the parallels $01^{\circ} \mathrm{S}$ and $18^{\circ} \mathrm{S}$ and the meridians $35^{\circ} \mathrm{W}$ and $47^{\circ} \mathrm{W}$ (Figure 1(a)). The climatic regime is semiarid for more than $80 \%$ of the area and the region often experiences dramatic droughts [1] and catastrophic floods (i.e., in May-June 2010 (http://www.lepoint.fr/monde/bresil-plus-de-1-000-disparusdans-les-inondations-dans-le-nord-est-22-06-2010-469027 24.php.)). The majority of the population lives along the coast, where the rainfall regime is mainly under the influence of the tropical oceanic climate [2-7]. The regular rainy season occurs from January to June in the eastern part of NEB localized between $2.5^{\circ} \mathrm{S}-12.5^{\circ} \mathrm{S} ; 40^{\circ} \mathrm{W}-35^{\circ} \mathrm{W}$ (Figure $1(\mathrm{a})$ ), with possible extensions of a few weeks before or after this period due to substantial interannual variability and distinctive subregional climate regimes. Differences in the length or intensity of the rainy season are due by several ocean-atmospheric processes or a combination of them.

Seasonal latitudinal migration across the equator of a zonal band of rainfall which is linked to the Inter-Tropical Convergence Zone (ITCZ) is the main mechanism of precipitation in this region [1]. The ITCZ reaches its southernmost latitude (i.e., directly over the northern NEB) in 


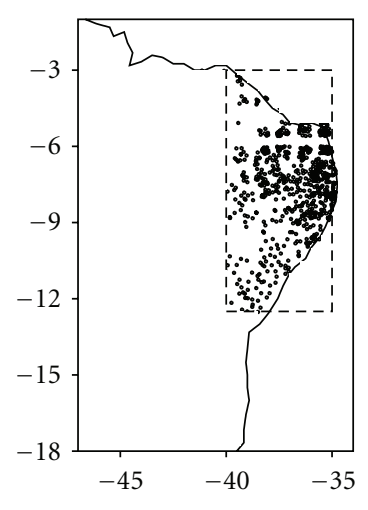

(a)

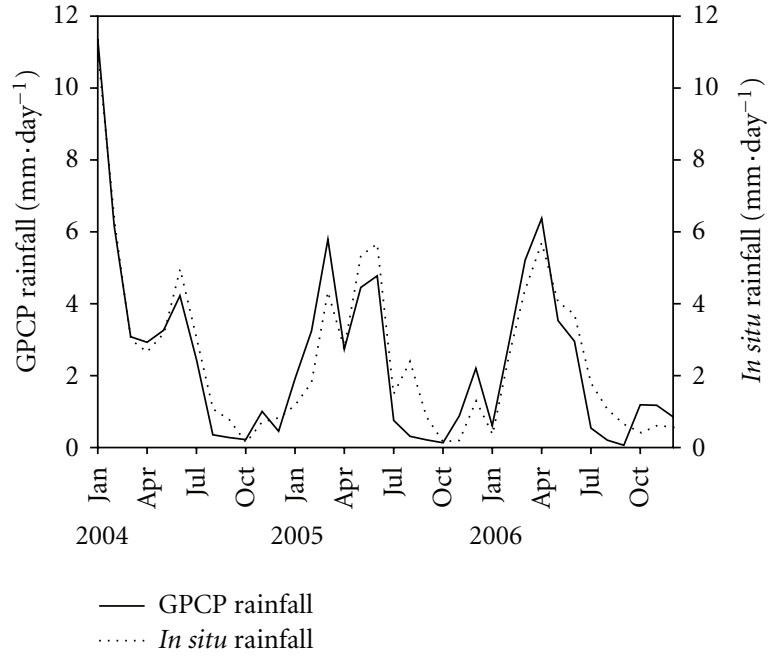

(b)

Figure 1: (a) Spatial distribution of 682 rain gauges over ENEB. (b) 2004-2006 GPCP and in situ monthly rainfall (mm·day ${ }^{-1}$ ) averaged over ENEB.

March-April in response to the seasonal warming of the adjacent tropical Atlantic Ocean. The interannual variability of the southward movement of the ITCZ is deeply affected by deviation of sea surface temperatures (SSTs) from their usual seasonal conditions over the tropical Atlantic. Such physical behavior is particularly important for the northern part of NEB [1].

The NEB rainy season is also often modulated by northward incursions of cold fronts coming from the South Atlantic Ocean. These cold fronts, sometimes linked to the strength of the episodic South Atlantic Convergence Zone (SACZ), cross the NEB in the north-westward direction from its southern coastline $\left(8^{\circ}-12^{\circ} \mathrm{S}\right)$ [8]. These events generate atmospheric instability and contribute to increased precipitation over all of NEB, especially in its midsouthern part.

Crossing the south-equatorial Atlantic basin from West Africa to South America [9-11], the atmospheric easterly waves (EWs) also constitute an important process in the seasonal rainfall regime over NEB. These waves are often associated with clusters of well-defined mesoscale convective systems (MCSs) [12, 13] that propagate westward above the oceanic basin reaching the NEB coast generating large amount of rainfall. For instance, Hall [14] showed a relationship between the passage of EWs and strong precipitation over Ascension Island $\left(7^{\circ} 55 \mathrm{~S}, 14^{\circ} 19 \mathrm{~W}\right)$ from March to May; Silvestre (unpublished material) and Torres and Ferreira [15] noted that such atmospheric perturbations can reach the NEB. Important for the rainfall in the eastern part of NEB (hereafter called ENEB) [16, 17], such behavior in the atmospheric circulation is the cornerstone of the present research.

The main objective of this study was to identify oceanatmosphere phenomena that could be related to strong rainfall episodes over ENEB, defined here as the region limited by $2.5^{\circ} \mathrm{S}-12.5^{\circ} \mathrm{S} ; 40^{\circ} \mathrm{W}-35^{\circ} \mathrm{W}$ (Figure $1(\mathrm{a})$ ). A simple diagnostic analysis was undertaken to estimate the relationship between strong precipitation episodes over ENEB and preconditioning occurrences of atmospheric and oceanic behaviors. This preliminary investigation was conducted over the rainy season of a three-year period (2004 to 2006) that included a representative number of strong rainfall episodes (hereafter defined as rainfall anomaly $>+10 \mathrm{~mm} \cdot \mathrm{day}^{-1}$ ). It was pointed that a significant percent of such strong rainfall episodes were associated to EW events. These cases (hereafter noted "true alarms") are the focus of our study, and they are largely documented in the present paper. Cases of strong rainfall anomaly not directly linked to EWs (hereafter noted "false alarm" cases), as well as marked EWs which did not have been followed by strong rainfall events, are not directly addressed in this study.

This paper is outlined as follows. Datasets are presented in the second section. An early diagnostic analysis, which used the three meteorological variables reported above (precipitation, MCS, EW) to select twelve occurrences during 2004-2006, is described and discussed in the third section. Further analyses using atmospheric and oceanic variables are developed and discussed in the fourth section. A conclusion is provided in the last section.

\section{Datasets}

The observed daily precipitation originated from two datasets. The 2004-2006 in situ daily datasets were constructed from an array of 682 meteorological stations in ENEB, with a higher spatial density in the coastal region east of $37^{\circ} \mathrm{W}$ (Figure 1(a)). These rainfall data were obtained from Brazilian regional meteorological services of Alagoas, Bahia, Ceará, Paraiba, Pernambuco, Rio Grande do Norte, and Sergipe States. The second precipitation dataset was extracted from the Global Precipitation Climatology Project (GPCP) [18] on a $1^{\circ} \times 1^{\circ}$ regular grid over all of NEB for the period 1997-2006. The GPCP dataset is composed by a combination 
of in situ observations with satellite microwave and infrared measurements. Although the spatial distributions of the data are quite different between these two data sources, the monthly rainfall averages over the same area (limited here by the in situ data source; Figure 1(a)) are very similar during the studied period 2004-2006 (Figure 1(b)). The seasonal variability is well marked, with maximum rainfall during the first semester (up to $6 \mathrm{~mm} \cdot$ day $^{-1}$ ) and very low amount of precipitation during the rest of the year. The interannual and intraseasonal variabilities (Figure 1(b)) are also significant, as, for instance, the exceptionally high precipitation observed in January (January is not considered as belonging to the regular wet season.) $2004\left(\sim 12 \mathrm{~mm} \cdot\right.$ day $\left.^{-1}\right)$ which was double of the monthly average precipitation recorded during the rainy season and the relatively low value of precipitation in April 2005 which was about the half of March and May values for the same year.

MCSs are usually identified by satellite digital images in the thermal infrared channel [19-21] and by meteorological radar [13]. In this study, we used the Météosat-7 images over the area $25^{\circ} \mathrm{N}-25^{\circ} \mathrm{S} ; 35^{\circ} \mathrm{W}-20^{\circ} \mathrm{E}$ from January to June during 2004, 2005, and 2006. These data were processed and archived at Centro de Previsão do Tempo e dos Estudos Climáticos of Instituto Nacional de Pesquisas Espaciais (CPTEC/INPE) and were available in 30-minute intervals with a horizontal resolution of $5 \mathrm{~km} \times 5 \mathrm{~km}$ at the subsatellite point. During its lifespan, each MCS moves, changes of form, intensity, and size, grows, decreases, dissipates, splits, or merges into one or more systems. To track each event in space and time during its full lifespan, it is necessary to use a method that is able to adapt to successive characteristic changes of the MCSs. Developed at CPTEC/INPE to analyze the physical characteristics of MCSs throughout their lifespan, the ForTraCC model [22] was used to track the convective systems during the three-year studied period. ForTraCC was previously adapted to different regions, primarily continental [23-27]. We used here a special adaptation (see Kouadio et al. [28] for more information) for tracking the MCSs over the ocean.

The EWs are depicted by the unfiltered relative positive vorticity computed from the wind field at $700 \mathrm{hPa}$ [11]. Molinari et al. [29] noted higher amplitudes of the easterly waves over Africa at $700 \mathrm{hPa}$ than at $900 \mathrm{hPa}$. Laurent et al. [13] also have shown that MCS propagations are associated with the midlevel flow with a best fit at $700 \mathrm{hPa}$ during easterly regime. We extracted these data from the National Center for Environmental Prediction-National Center for Atmospheric Research (NCEP-NCAR) 1997-2006 reanalysis [30] for the same periods as those for the Météosat-7 images. Daily data of unfiltered relative positive vorticity were reported on a $2.5^{\circ} \times 2.5^{\circ}$ grid.

Complementing the three meteorological variables described above, daily vertical profiles $(500-1000 \mathrm{hPa})$ of zonal wind, vertical velocity, specific humidity, and latitude-longitude patterns of latent heat $(\mathrm{LH})$ were extracted from the daily outputs of the NCEP-NCAR 1997-2006 reanalysis [11, 30] for the same oceanic study domain.

Weekly SST anomaly fields were derived from the weekly SST 1993-2006 climatology of Reynolds et al. [31] for a better insight into the low-frequency variability of the oceanic thermal conditions and to compare the departure of SST and oceanic heat content. These data, extracted from the IRI/LDEO Climate Data Library (http://iridl.ldeo.columbia .edu/), were provided on a $1^{\circ} \times 1^{\circ}$ grid. $\mathrm{HC}$ was defined as the oceanic heat content within the layer between the surface and the depth of the $20^{\circ} \mathrm{C}$ isotherm. HC weekly values were computed on a $1^{\circ} \times 1^{\circ}$ grid for the period 1993-2006 through an original combination of variables processed within a 1.5 reduced gravity model [31]. These variables were the following: (i) weekly altimeter-derived sea level anomalies from Archiving Validation and Interpretation of Satellite Oceanographic Data (AVISO) (http://www.aviso .oceanobs.com/), (ii) weekly SST from the Tropical Rainfall Measuring Mission (TRMM) microwave imager (http://disc .sci.gsfc.nasa.gov/precipitation/documentation/TRMM README/TRMM_2A12_readme.shtml), and (iii) monthly climatic subsurface hydrological data from the World Ocean Atlas 2001 (WOA01) (http://www.nodc.noaa.gov/ OC5/WOA01/pr_woa01.html). Details of the methodology employed are described by Arruda et al. [32] and Arruda and Lentini [33].

\section{Diagnostic Analysis and Selection of the "True Alarm" Events}

The three panels of Figure 2 show MCS behaviors in the area $5^{\circ} \mathrm{N}-12.5^{\circ} \mathrm{S} ; 40^{\circ} \mathrm{W}-20^{\circ} \mathrm{E}$ for the January to May periods in 2004, 2005, and 2006 (panels (a), (b), and (c), resp.). The seasonal average of the monthly precipitations during Januaryto-May is also represented. Due to the large amount of MCSs, only those with a westward lifespan longer than 10 hours and those that dissipated between $2.5^{\circ} \mathrm{S}$ and $12.5^{\circ} \mathrm{S}$ are illustrated. Neither the curves of the trajectories nor the spreading surfaces of the MCSs are represented; instead, the onset represented by black dots on the figure, and dissipation coordinates are depicted and linked by a straight line. In order to keep a continuously MCS life cycle, the onset (dissipation) coordinates are defined as being the positions of the MCSs in the first (last) available images where the brightness temperature is less (greater) than a specific threshold as function of the diurnal cycle (for details see [28]). Figure 2 shows that the MCSs were essentially spread out into three regions. Two regions with a larger meridional extension and a higher MCS density are as follows: a first one in West Africa with a westward extension up to $5^{\circ} \mathrm{E}$, a second one from $20^{\circ} \mathrm{W}$ to the South American coast. The third region, with a weaker MCS density, was trapped along the zonal band between the Equator and $5^{\circ} \mathrm{S}$, from $20^{\circ} \mathrm{W}$ to $5^{\circ} \mathrm{E}$. Many MCS occurrences during January to May regenerated by multiple phenomena of merges or splits (not shown). The MCS tracking showed four interesting behaviors: (i) all MCSs that started in Africa dissipated towards $5^{\circ} \mathrm{E}$ and never reached NEB (or at least they were not visible from the ForTraCC analysis); (ii) all MCSs that dissipated close to the South American coast initiated at west of $20^{\circ} \mathrm{W}$; (iii) most of the MCSs that were moving northward or southward in the western Atlantic converged thru the coastal ENEB; (iv) a lack 


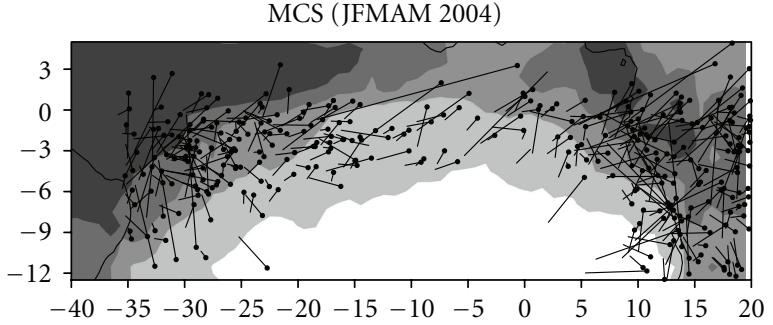

(a)

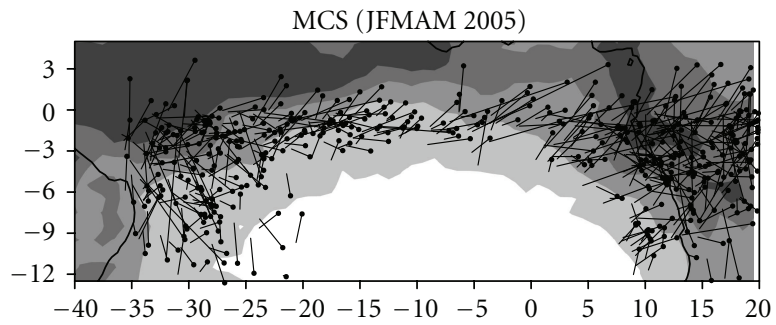

(b)

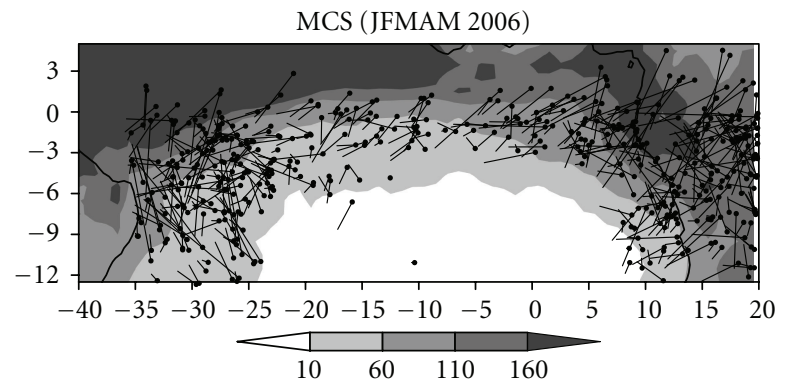

(c)

FIGURE 2: MCSs (lifespan $>10$ hours) that moved westward in the area $5^{\circ} \mathrm{N}-12.5^{\circ} \mathrm{S}, 35^{\circ} \mathrm{W}-20^{\circ} \mathrm{E}$ during January-May in (a) 2004 , (b) 2005 , and (c) 2006 are depicted by straight lines linking onset (black dots) and dissipation coordinates. Shaded contours represent seasonally average of the monthly precipitations $\left(\mathrm{mm} \cdot \mathrm{month}^{-1}\right)$ in JFMAM.

of MCS was noted at south of $5^{\circ} \mathrm{S}$, that is, over the southern subtropical high.

To understand the importance of the MCSs in the ENEB precipitation regime and to verify how these systems are related to the large scale positive vorticity anomalies, the monthly rainfall averaged over ENEB was plotted together with the monthly number of MCS occurrences along the Brazilian coast, and the monthly positive unfiltered relative vorticity at $700 \mathrm{hPa}$ over the southern tropical Atlantic. Figure 3(a) shows the seasonal monthly rainfall averaged from the GPCP dataset during 1997-2006 over ENEB and the averaged monthly vorticity at $700 \mathrm{hPa}$, during the same period, over the region $2.5^{\circ} \mathrm{S}-12.5^{\circ} \mathrm{S} ; 40^{\circ} \mathrm{W}-20^{\circ} \mathrm{E}$. Both datasets are in very good agreement, showing a larger precipitation signal $\left(>3 \mathrm{~mm} \cdot \mathrm{day}^{-1}\right)$ during the wet season, simultaneously with an increase in positive unfiltered relative vorticity $\left(>710^{-8} \cdot \mathrm{s}^{-1}\right)$. Indeed, the monthly average vorticity is higher $(\times 1.5$ times $)$ during the first semester than during the rest of the year, indicating an increasing of EW occurrences during that period over the southern tropical Atlantic basin. The evolutions of these two former monthly parameters were plotted together (Figure 3(b)) with a monthly index of MCS occurrences during the three years studied here (2004-2005-2006). On this figure, the monthly index of MCS occurrences is represented by the monthly number of MCSs, (The MCS monthly index value was not plotted when there swas a lack of Météosat data imagery longer than 15 days during a given month.) (with lifespan > 2 hour) which moved in the westward direction inside the region $2.5^{\circ} \mathrm{S}-12.5^{\circ} \mathrm{S} ; 35^{\circ} \mathrm{W}-20^{\circ} \mathrm{W}$. The seasonal evolution of this MCS index (dashed line) was similar to that of the
ENEB precipitation (solid line, in $\mathrm{mm} \cdot \mathrm{day}^{-1}$ ) and monthly vorticity index (light dashed line, in $10^{-7} \cdot \mathrm{s}^{-1}$ ); a high (low) number of MCSs was generally associated with abundant (low) precipitation over the ENEB and strong (weak) positive unfiltered relative vorticity.

These last results indicate a monthly relationship between positive westward propagation of positive unfiltered relative vorticity over the southern tropical Atlantic, MCS occurrences over the west southern tropical Atlantic, and strong precipitation events over the ENEB. To look in details of this relationship at a higher frequency, a daily analysis was performed over these variables during the first semesters of the three studied years. Figure 4 shows the positive daily vorticity at $700 \mathrm{hPa}$ averaged between $2.5^{\circ} \mathrm{S}$ and $12.5^{\circ} \mathrm{S}$ along $40^{\circ} \mathrm{W}-20^{\circ} \mathrm{E}$ for the first semester of 2004 , 2005, and 2006 (panels (a), (b), and (c), resp.). Many EW trains crossed the Atlantic basin from West Africa to South America. All the occurrences of strong positive anomalies of daily (GPCP) precipitation $\left(>10 \mathrm{~mm} \cdot \mathrm{day}^{-1}\right)$ over ENEB are shown in Figure 4 by black dots along the meridian $36^{\circ} \mathrm{W}$, that is, about the mean longitude of the coastal line of this subregion (see Figure 1(a)). These rainfall anomalies were computed as the differences between the GPCP daily rainfall values, averaged inside the domain $2.5^{\circ} \mathrm{S}-12.5^{\circ} \mathrm{S} ; 40^{\circ} \mathrm{W}-$ $35^{\circ} \mathrm{W}$ during the three semesters of 2004,2005 , and 2006 , and the climatic precipitation averaged over the same region during the same calendar days for the period 1997-2006.

A large part of the strong rainfall events (some of them lasting more than one day) appeared to be directly related to EWs. Focusing on these last episodes (i.e., the "true alarms", as defined previously), we selected the EWs with 


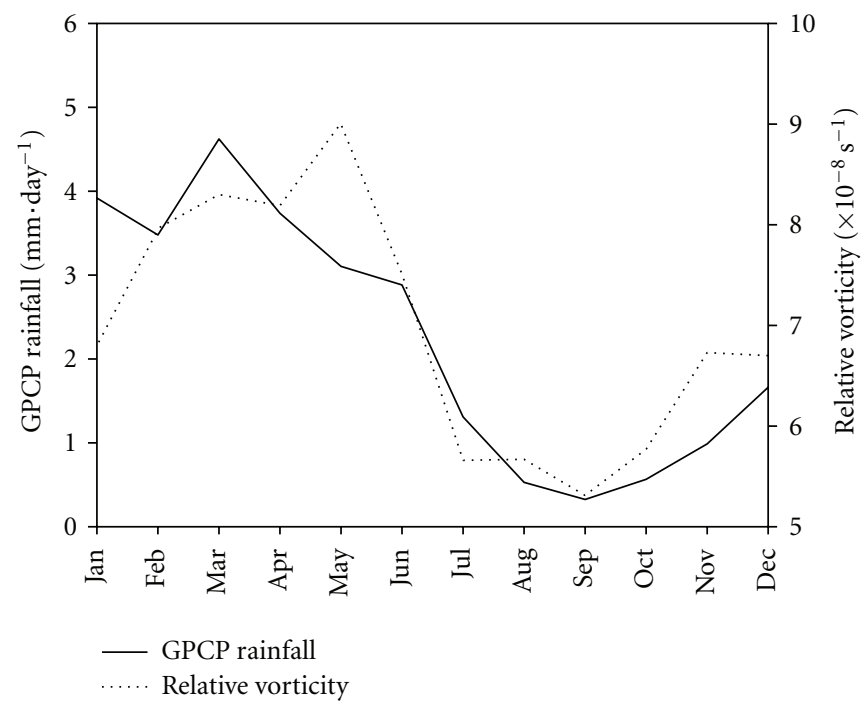

(a)

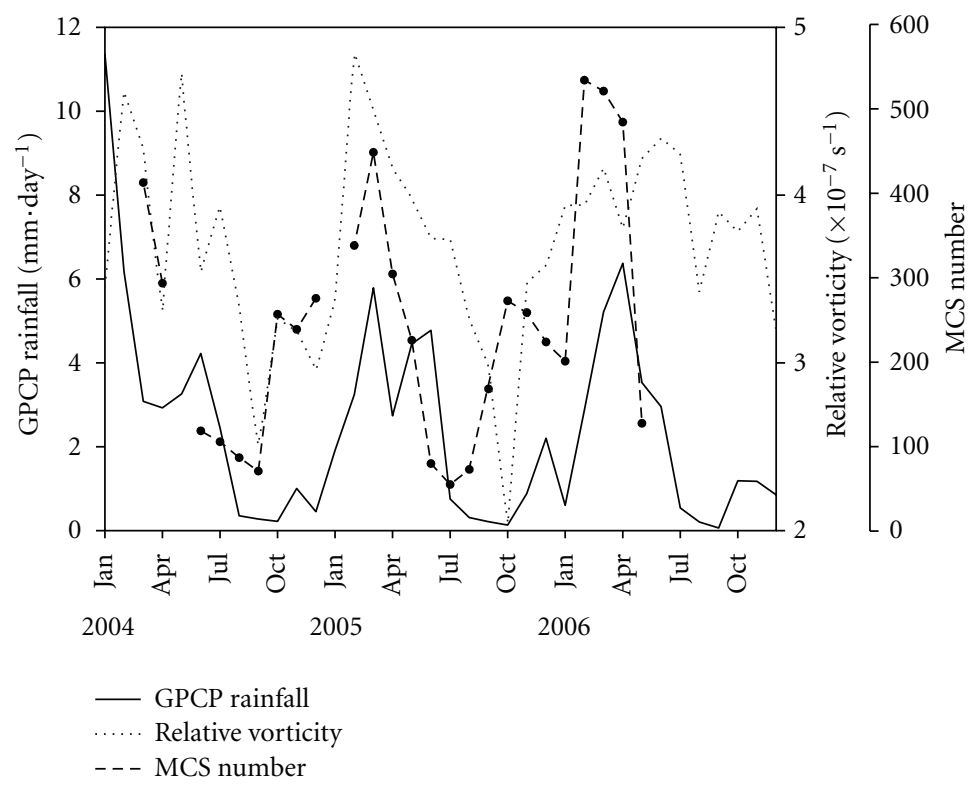

(b)

FIGURE 3: (a) Monthly climatology averaged for the period 1997-2006 of GPCP rainfall (solid line, mm·day ${ }^{-1}$ ) calculated over ENEB and $700 \mathrm{hPa}$ positive vorticity (light dashed line, $10^{-8} \cdot \mathrm{s}^{-1}$ ) inside the area $2.5^{\circ} \mathrm{S}-12.5^{\circ} \mathrm{S}, 40^{\circ} \mathrm{W}-20^{\circ} \mathrm{E}$. (b) Same as (a) during the three years 2004-2006; Monthly number of MCSs (lifespan > 2 hours) that moved westward (dashed-dotted line) from $20^{\circ} \mathrm{W}$ up to ENEB and had a dissipation coordinate ranging between $2.5^{\circ} \mathrm{S}$ and $12.5^{\circ} \mathrm{S}$.

the following characteristics: (i) they started (at least) east of $20^{\circ} \mathrm{W}$; (ii) they had a duration higher or equal to three days; (iii) they reached (at least) the coast of ENEB (i.e., $36^{\circ} \mathrm{W}$ ) thesame day (or the first day) of the noted strong rainfall episodes; (iv) they were associated with one or more strong MCSs (lifespan $>2$ hours) that moved westward in the vicinity of ENEB. This simple diagnostic technique highlighted twelve cases, five during the first semesters of 2004 and 2005 and two during the first semester of 2006. These twelve EW occurrences, shown in Figure 4 by dashed lines from the day of the onset spots of the waves (marked by squares) to the day (or the first day) of the strong rainfall spots (marked by black dots), had a phase speed ranging between 5.2 and $11.9 \mathrm{~m} \cdot \mathrm{s}^{-1}$ (average of $4.9 \mathrm{~m} \cdot \mathrm{s}^{-1}$ ) and a period ranging between 3 and 8 days (average of 4.9 days) (see Table 1). Eleven of these twelve selected EWs started in the open ocean west of $5^{\circ} \mathrm{E}$; only one event (in June 2004) initiated very close to the African continent, at $10^{\circ} \mathrm{E}$.

Two other scenarios were also observed in Figure 4. According to the first scenario, it seems that for a smaller number of cases (e.g., in May 2004, June 2005, June 2006) the strong rainfall events (anomalies $>10 \mathrm{~mm} /$ day) were not 


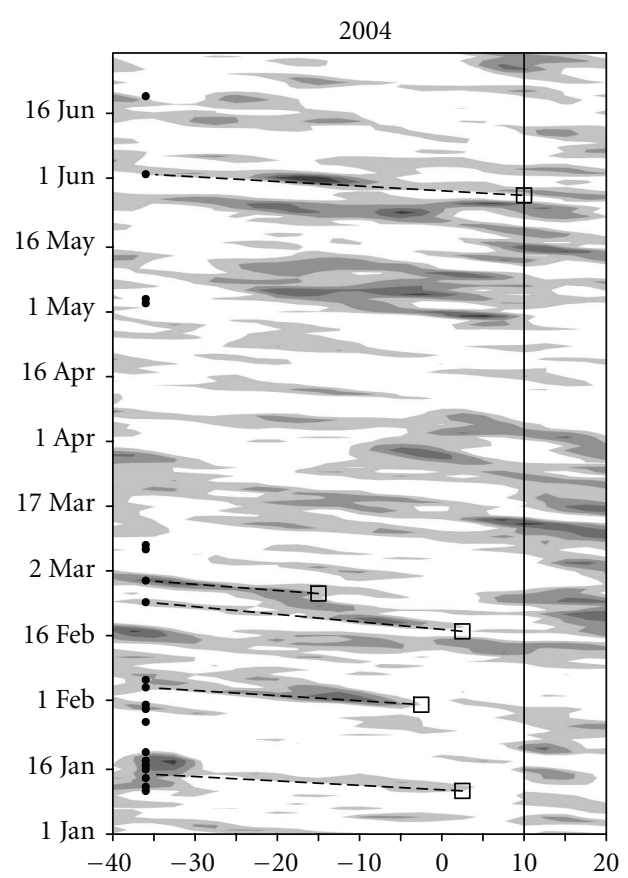

(a)

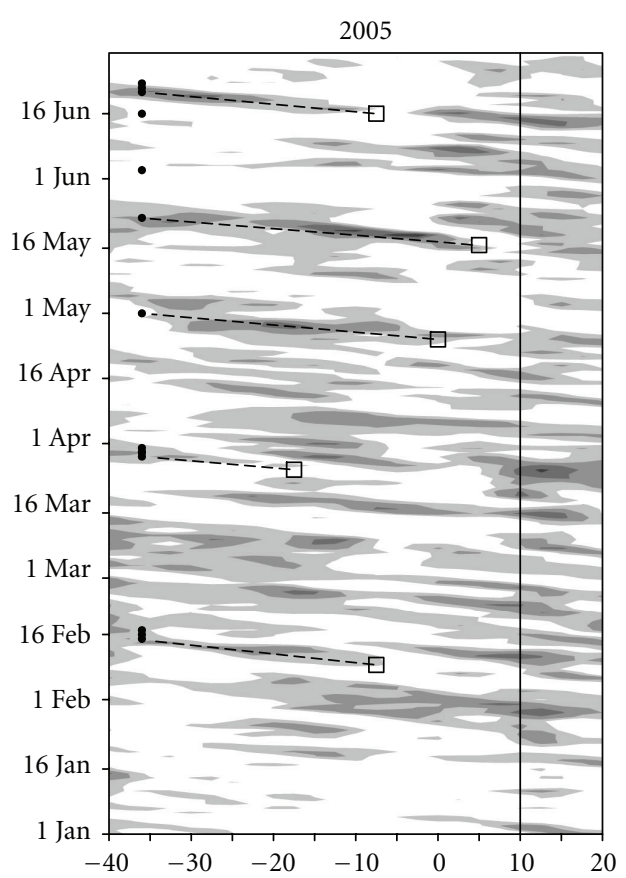

(b)

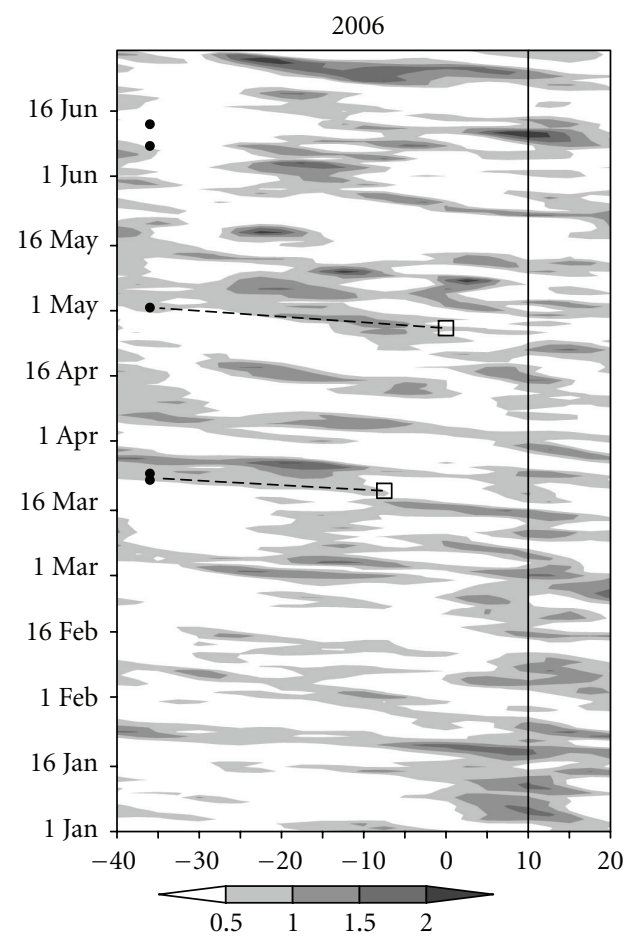

(c)

Figure 4: $700 \mathrm{hPa}$ daily positive vorticity $\left(10^{-5} \cdot \mathrm{s}^{-1}\right)$ from January-June in (a) 2004, (b) 2005, and (c) 2006 along $40^{\circ} \mathrm{W}-20^{\circ} \mathrm{E}$ averaged between $2.5^{\circ} \mathrm{S}$ and $12.5^{\circ} \mathrm{S}$. The vertical solid line at $10^{\circ} \mathrm{E}$ represents the approximate eastern limit of the African continent. Positive strong daily rainfall anomalies $\left(>10 \mathrm{~mm} \cdot \mathrm{day}^{-1}\right)$ over ENEB are schematized by black dots at $36^{\circ} \mathrm{W}$. Selected EW onsets, marked by squares, are connected by a dashed line to the strong rainy events.

associated with marked EW occurrences. These strong anomaly events can be explained by the further ocean-atmosphere physical processes already presented in the introduction, that is, the abnormal southward migration of the ITCZ
[1] or the incursions of cold fronts coming from the South Atlantic [8]. The second scenario, depicted here as "false alarms", related some EWs in 2004, 2005, and 2006 which were not associated to strong rainfall events over ENEB. 
TABLE 1: Characteristics of the twelve selected events observed in 2004, 2005, and 2006. The day (or first day) of strong rainfall episode over ENEB, duration (days) of strong rainfall episode, EW onset date, lifespan (days) of EW, EW virtual velocity $\left(\mathrm{m} \cdot \mathrm{s}^{-1}\right.$ ) are given for each event.

\begin{tabular}{|c|c|c|c|c|c|}
\hline Year & $\begin{array}{l}\text { Day (first day) of the strong } \\
\text { rainfall episode }\end{array}$ & $\begin{array}{l}\text { Duration of the strong } \\
\text { rainfall episode (days) }\end{array}$ & EW onset date & Lifespan of EW (days) & $\begin{array}{l}\text { EW virtual velocity } \\
\left(\mathrm{m} \cdot \mathrm{s}^{-1}\right)\end{array}$ \\
\hline \multirow{5}{*}{2004} & Jan 14 & 1 & Jan 11 & 3 & 11.9 \\
\hline & Feb 04 & 2 & Jan 31 & 4 & 8.3 \\
\hline & Feb 25 & 1 & Feb 17 & 8 & 5.2 \\
\hline & Feb 28 & 1 & Feb 25 & 3 & 8.5 \\
\hline & Jun 01 & 1 & May 28 & 4 & 11.7 \\
\hline \multirow{5}{*}{2005} & Feb 15 & 3 & Feb 9 & 6 & 6.8 \\
\hline & Mar 27 & 4 & Mar 24 & 3 & 8.5 \\
\hline & May 02 & 1 & Apr 25 & 7 & 5.7 \\
\hline & May 23 & 1 & May 15 & 8 & 6.5 \\
\hline & Jun 23 & 3 & Jun 16 & 7 & 5.2 \\
\hline \multirow{3}{*}{2006} & Mar 23 & 2 & Mar 20 & 3 & 8.8 \\
\hline & Apr 30 & 1 & Apr 27 & 3 & 7.8 \\
\hline & & & Average & 4.9 & 7.9 \\
\hline
\end{tabular}

Such both scenarios will be discussed in an earlier work to help in the extended understanding of the ocean-atmosphere conditions that influence the strong rainfall episodes on ENEB.

We will now focus on the twelve strong rainy events which were associated with westward positive unfiltered relative vorticity anomalies. As one example, Figure 5 shows the 20-23 March 2006 event which had an EW/positive anomaly of 3-day lifespan with a velocity of $8.8 \mathrm{~m} \cdot \mathrm{s}^{-1}$ resulting in a 2day strong rainfall event starting March 23 (see Table 1). The left panel of Figure 5 is related to the daily latitude-longitude pattern of the propagation of the $700 \mathrm{hPa}$ unfiltered relative vorticity $\left(\times 10^{-5} \mathrm{~s}^{-1}\right)$ from the day of the EW initiation (20 March) up to the first day when the strong rainfall episode was observed in ENEB ( 23 March). Two cells of vorticity were noted inside the $2.5^{\circ} \mathrm{S}-12.5^{\circ} \mathrm{S}$ latitudinal band: the first one is close to the African continent and stopped at around $0^{\circ} \mathrm{E}$, thus without influence over NEB precipitation. The second cell of vorticity initiated at around $10^{\circ} \mathrm{W}$ (March 20) and propagated westward up to the American continent. On the right panel of Figure 5 the date of the first day of strong rainfall over ENEB (March 23) is marked by a dot, and the westward MCS trajectories ( $>2$-hour) with various life cycles are superimposed. These MCS westward trajectories followed and embedded the second EW from March 22, indicating propagating convective activities between $20^{\circ} \mathrm{W}$ and ENEB, in agreement with what was suggested by Bartels and Maddox [34]. Furthermore, the intermittent episodes of dissipation/initiation merging/splitting of MCS could have a positive feedback in intensifying the positive vorticity.

Figure 6 shows two examples of MCS behavior at 30 minutes interval. These two events were chosen because the duration and space scale of the two associated strong-rainy episodes were very different from each other (see Table 1). The first strong-rainy episode (Figure 6(a)) lasted four days (27-30 March 2005), while the second event (Figure 6(b)) lasted only one day (30 April 2006). The 30-min spreading areas (represented here as circles proportional to the cloudcovered area) of the MCSs related to the event of 27-30
March 2005 were considerably larger and covered the whole ENEB, some of them spreading above the ocean up to $25^{\circ} \mathrm{W}$. Their centers of mass were found between the longitudes $36^{\circ} \mathrm{W}$ and $30^{\circ} \mathrm{W}$. In contrast, the spreading areas of the MCSs related to the 30 April 2006 event were small and only partially covered the ENEB. Furthermore, their centers of mass were mainly localized close to the coast.

Interesting complementary information of the ENEB rainfall during the full years of 2004, 2005, and 2006 is illustrated in Figures 7 and 8. Figure 7 shows the daily time series of the GPCP precipitation anomalies over the study region. Twenty-four strong episodes (anomaly $>10 \mathrm{~mm} \cdot \mathrm{day}^{-1}$ ) were observed during each first semester of the 3-year period: thirteen in 2004, seven in 2005, and four in 2006. The twelve previously selected events associated with EWs are indicated by stars on Figure 7. They represented a suitable proportion (half of the cases) of the strong rainfall episodes, especially in 2005 when the proportion exceeded $70 \%$ of the cases. Figure 8 shows the ratio between the daily rainfall amount during each calendar day and the cumulated monthly rainfall amount calculated during the current month. Only the months with at minimum one selected event are illustrated. The twelve selected events are marked by black bars for one or more successive days (maximum 4 days). As noted above, the individual contribution of the selected events was especially higher in 2005; for example, the 3-day (4-day) event selected in February 2005 (March 2005) had a cumulative precipitation representing 60\% (48\%) of the total amount for the corresponding month.

\section{Overview of the Atmospheric Circulation and Ocean Thermal Conditions during the Selected "True Alarm" Events}

Specific conditions of atmospheric circulation and oceanic patterns that could help in triggering and sustaining the selected "true alarm" rainy events are discussed in this section. The following variables have been analyzed during 

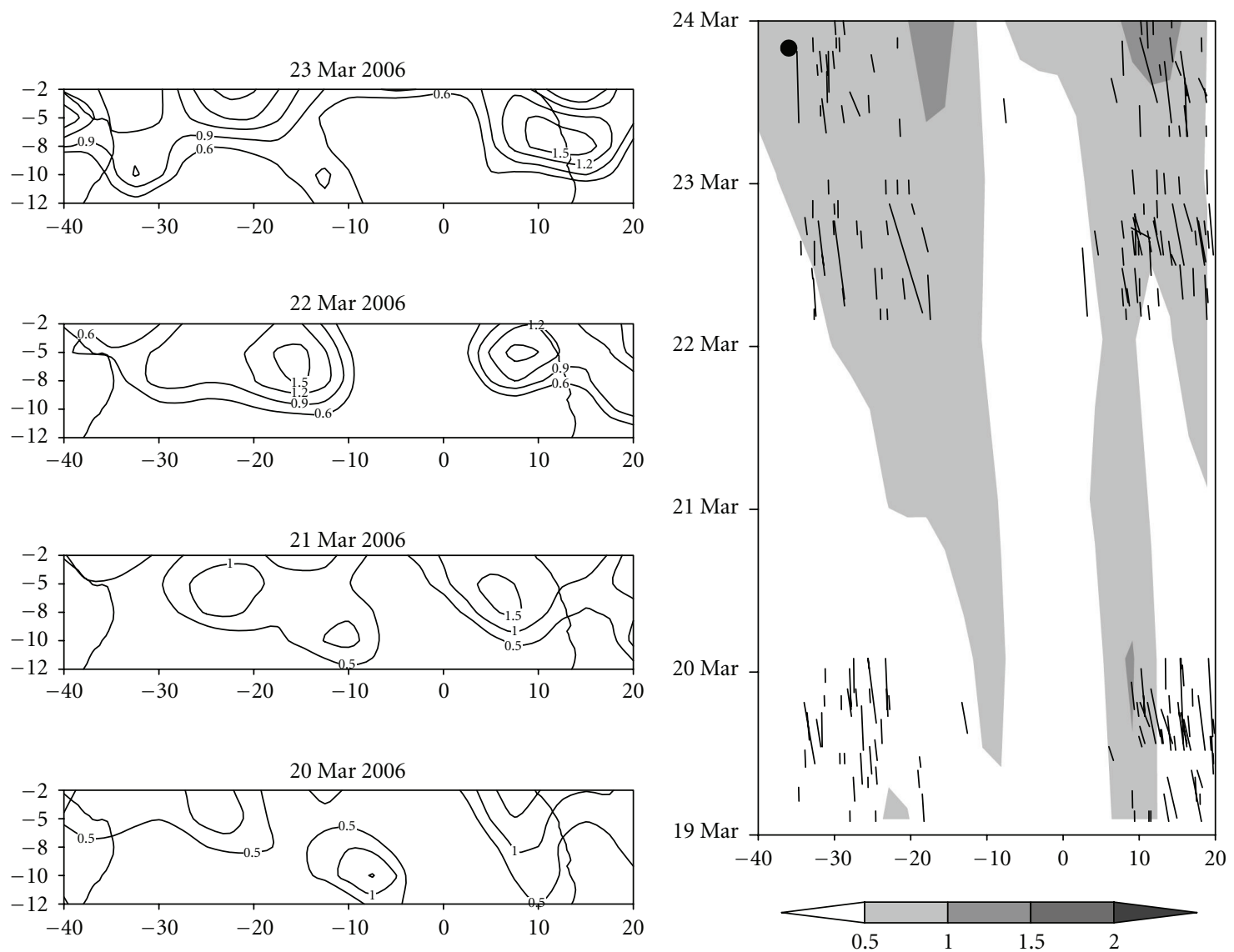

(a)

(b)

Figure 5: Zoom over the event of 20-23 March 2006: (a) daily pattern of the $700 \mathrm{hPa}$ unfiltered positive vorticity $\left(\times 10^{-5} \mathrm{~s}^{-1}\right)$; (b) the corresponding time-longitude diagram along $40^{\circ} \mathrm{W}-20^{\circ} \mathrm{E}$ averaged on $2.5^{\circ} \mathrm{N}-12^{\circ} 5 \mathrm{~S}$. The date of the first day of strong rainfall over ENEB is marked as dot. The westward MCS trajectories ( $>2$ hours) are plotted.

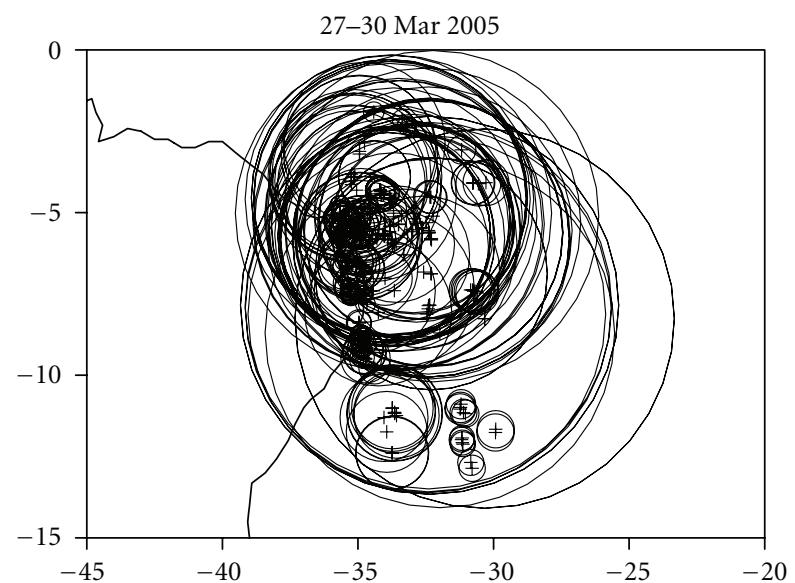

(a)

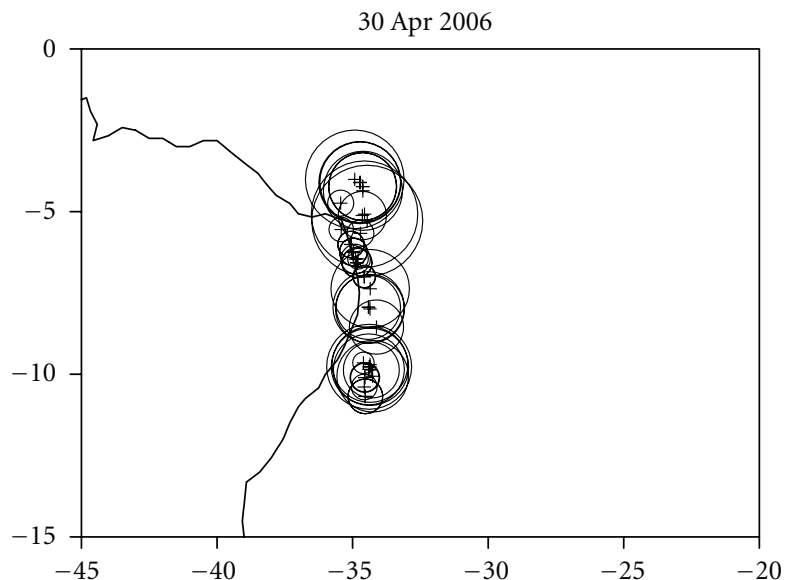

(b)

Figure 6: Two examples (27-30 March 2005 (a) and 30 April 2006 (b)) at 30-minute interval of the spreading behaviors of MCSs (represented as circles with proportional area and centers of mass as crosses) that were associated with the two corresponding strong rainy selected events (see Table 1 and Figure 7). 


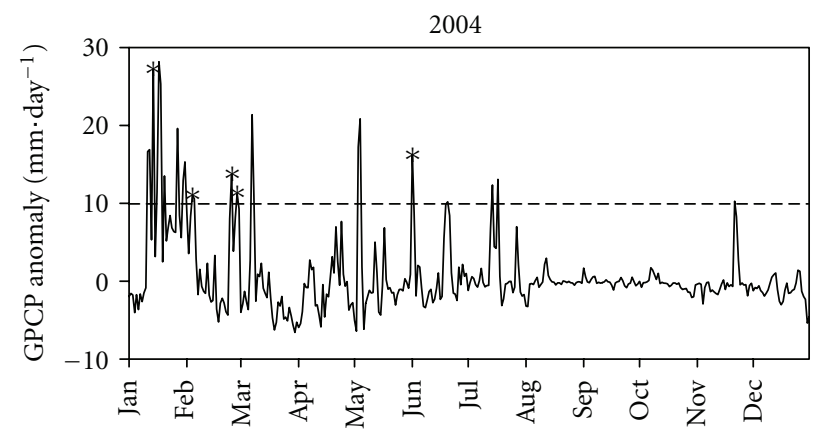

(a)

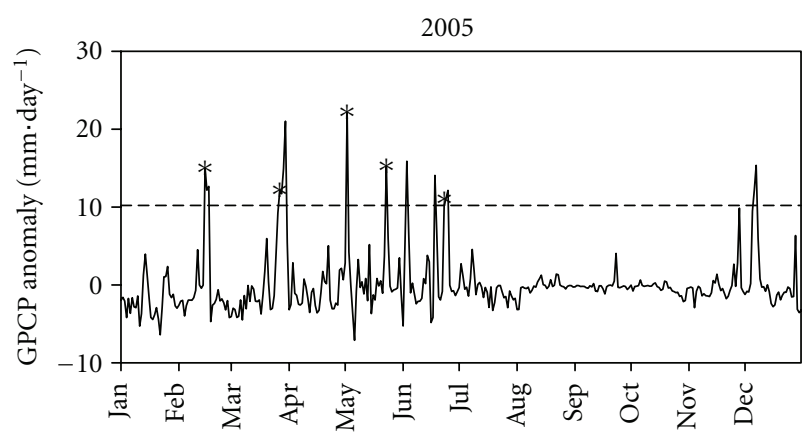

(b)

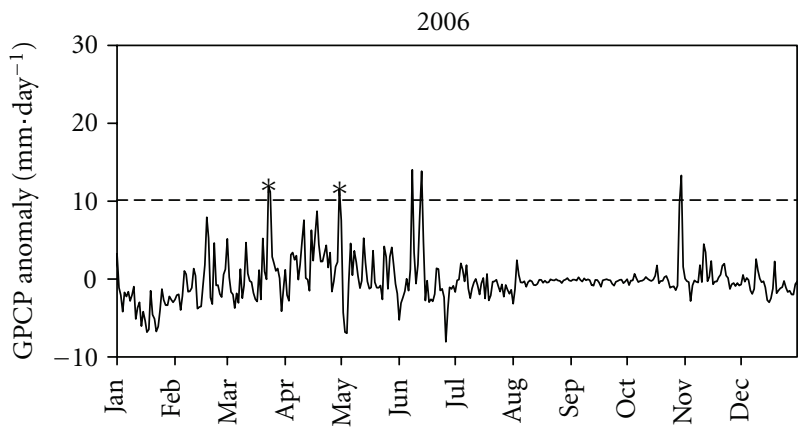

(c)

Figure 7: Daily time series of GPCP anomalies $\left(\mathrm{mm} \cdot\right.$ day $^{-1}$ ) calculated over ENEB in 2004 (a), 2005 (b), and 2006 (c) from the climatic precipitation, averaged over the same region during the same calendar days for the period 1997-2006. The horizontal dashed line at $10 \mathrm{~mm} \cdot$ day $^{-1}$ represents the limit used to identify the strong precipitation episodes. The twelve selected events are marked by stars (see Table 1 and Figure 8). The tick marks on the $x$-axis represent the first day of corresponding month.

the twelve episodes inside the south-equatorial oceanic basin $\left(2.5^{\circ} \mathrm{S}-12.5^{\circ} \mathrm{S} ; 40^{\circ} \mathrm{W}-20^{\circ} \mathrm{E}\right)$ : zonal wind, vertical velocity, and specific humidity within the troposphere $(500$ $1000 \mathrm{hPa}$ ), as well as LH, SST, and HC. Twelve-event-composite patterns of the atmospheric (oceanic) parameters were constructed by averaging the daily (weekly (For SST and HC, we selected the week the closest of the daily events.)) values during the twelve periods occurring just before the date of the twelve selected strong rainfall events. These periods (as described in Figure 4 and in Table 1) were defined as starting the day of the EW/positive vorticity event onset and ending the day (or first day) of the observed strong rainfall episode. The composite anomalies were computed during the same calendar periods using the arithmetic differences between the previous 12-event-composite patterns and the composite patterns using the long-term climatology databases (19972006 for the atmospheric variables and SST for Figures 913 and 1993-2006 (The 1971-2000 reference is the original SST reference period used by Reynolds et al. [31] but here we used the 1993-2006 reference period (see Figure 14) to compare the SST anomalies with the HC anomalies during the available period of $\mathrm{HC}$ dataset [32].) to compare SST and $\mathrm{HC}$ on Figure 14). Moreover, for a better insight into the low-frequency variability of the oceanic thermal conditions, we computed and compared the departure of SST and HC during each first semester of the 3-year study.
4.1. Atmospheric Circulation Variability. Figure 9 shows the altitude-longitude zonal wind composites for the twelve selected events (Figure 9(a)) and their associated anomalies (Figure 9(b)), averaged over $2.5^{\circ} \mathrm{S}-12.5^{\circ} \mathrm{S}$ along $40^{\circ} \mathrm{W}-20^{\circ} \mathrm{E}$ from 500 to $1000 \mathrm{hPa}$. The dashed vertical line around $36^{\circ} \mathrm{W}$ represents the mean longitude of the ENEB coast. Negative zonal-wind values (in $\mathrm{m} \cdot \mathrm{s}^{-1}$ ) in the lower layer are related to the usual easterly trades, with maxima $\left(>6.0 \mathrm{~m} \cdot \mathrm{s}^{-1}\right)$ within the longitudes $30^{\circ} \mathrm{W}-15^{\circ} \mathrm{W}$ (Figure $9(\mathrm{a})$ ). An abnormal intensification of these easterlies $\left(>0.5 \mathrm{~m} \cdot \mathrm{s}^{-1}\right)$ was noted in the departure composite of the selected events in the 700$1000 \mathrm{hPa}$ layer, particularly within the longitudes $20^{\circ} \mathrm{W}-$ $5^{\circ} \mathrm{E}$ (Figure 9(b)). Notably, this band corresponds to the longitudinal band where the selected EWs started (see Figure 4).

Figure 10 depicts the altitude-longitude composite diagrams of the vertical velocity (in $10^{-3} \mathrm{hPa} \cdot \mathrm{s}^{-1}$ ) over the same area. Negative values indicate an upward motion of air, which can carry moisture from the ocean to the troposphere, while positive values indicate a subsidence of air. Both the composite pattern (Figure 10(a)) and the composite anomaly pattern (Figure 10(b)) illustrates what occurred, on average, during the twelve selected events. The vertical motion composite shows an upward motion within the whole troposphere in the western basin, whereas it was weakly downward east of $20^{\circ} \mathrm{W}$ except just above the sea surface, where it was 
(\%)

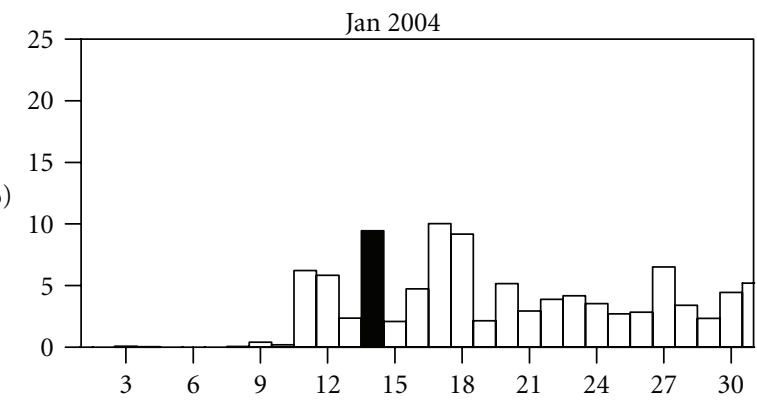

(\%)

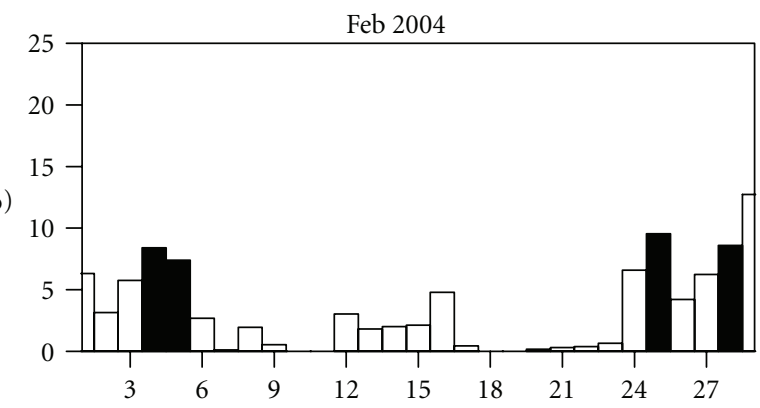

(\%)
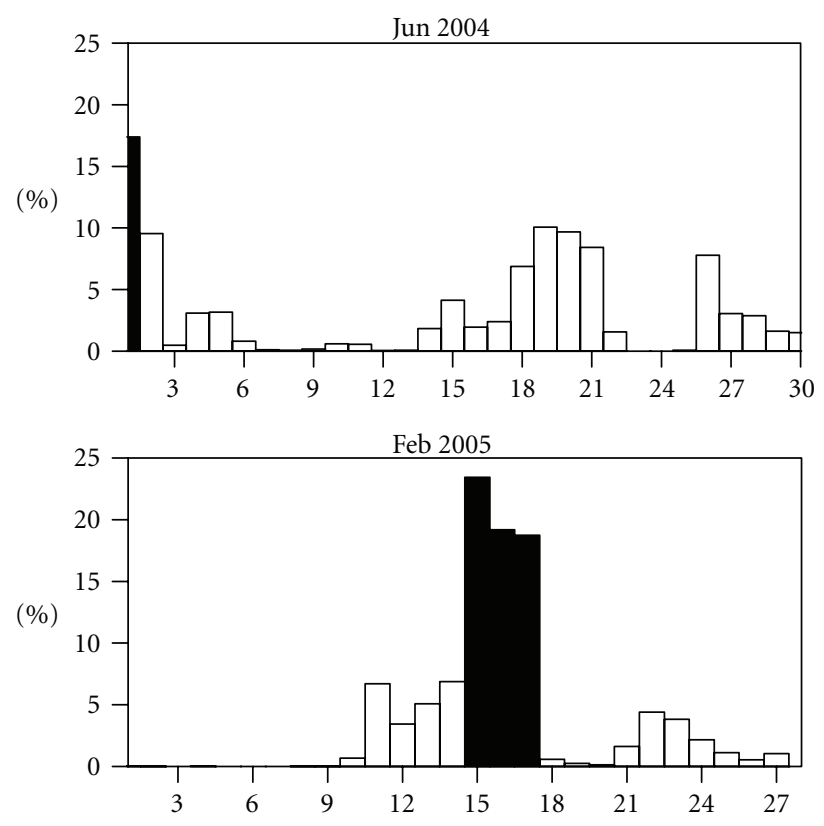

(\%)

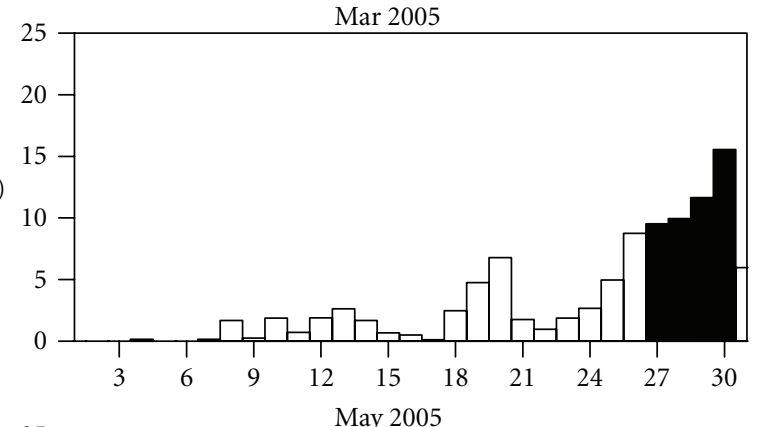

(\%)

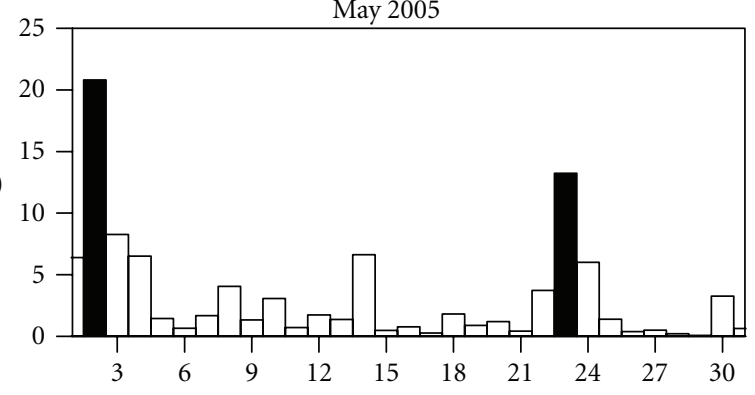

Jun 2005
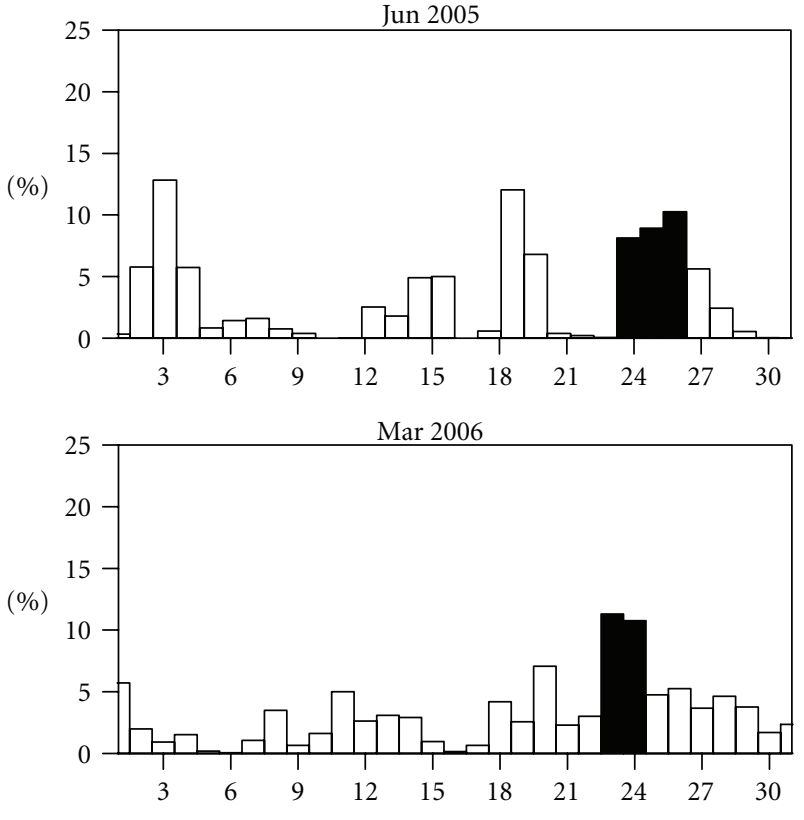

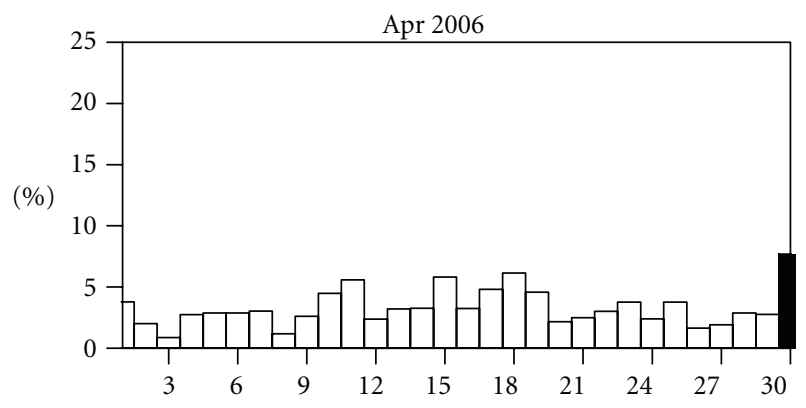

Figure 8: Ratio (\%) between individual daily rainfall amount and monthly cumulative rainfall amount during the months when one or more selected events occurred. The twelve selected events (from 1-to-4 day duration; see Table 1) are marked by black bars. 


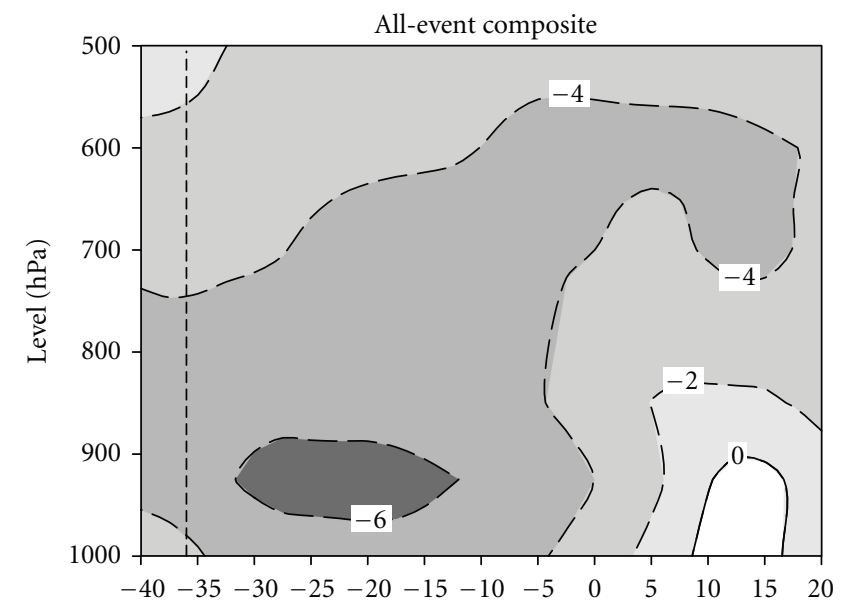

(a)

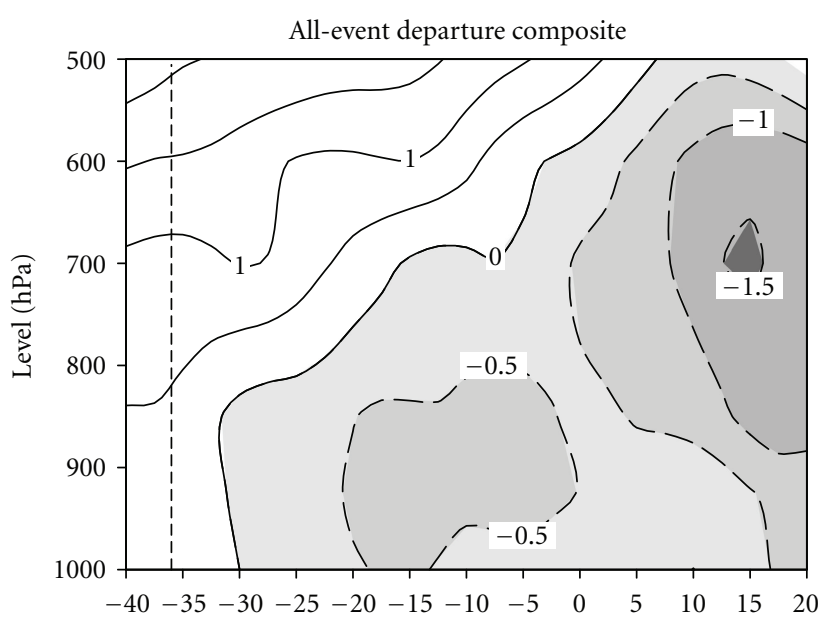

(b)

FIgURE 9: Altitude-longitude composite values (a) and composite anomalies (b) of zonal wind $\left(\mathrm{m} \cdot \mathrm{s}^{-1}\right)$ averaged over $2.5^{\circ} \mathrm{S}-12.5^{\circ} \mathrm{S}$ during the periods of the twelve selected events from the onset of EWs until the day (or first day) of strong rainfall anomaly episodes over ENEB. The vertical dashed line at $36^{\circ} \mathrm{W}$ schematizes the mean longitude of littoral ENEB. Easterlies (negative values) are shaded.

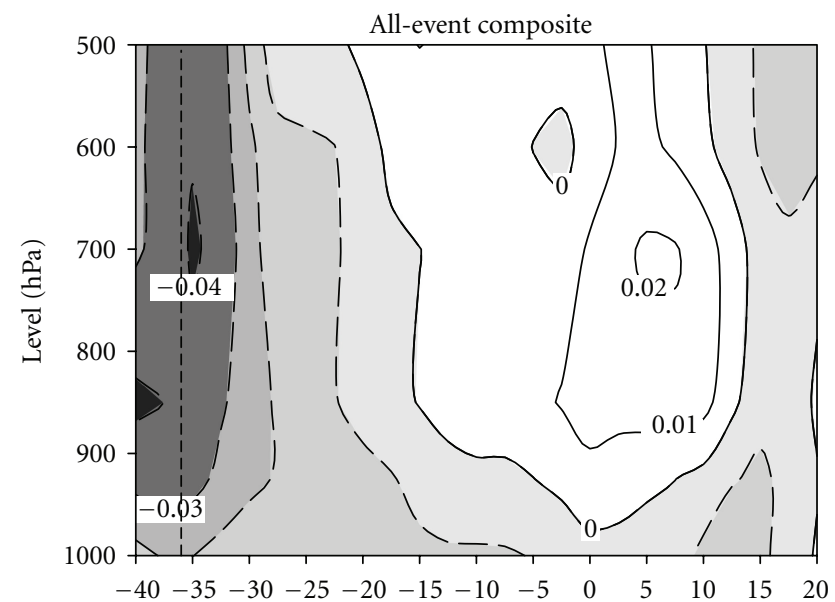

(a)

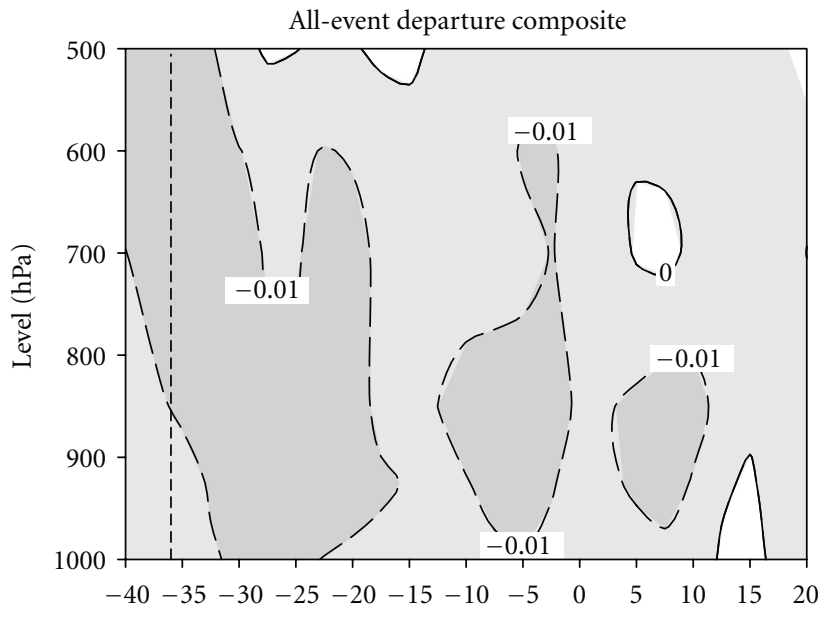

(b)

FIGURE 10: Same as Figure 8 but for the vertical velocity $\left(10^{-3} \mathrm{hPa} \cdot \mathrm{s}^{-1}\right)$. Upward motion (negative values) is shaded.

continually upward all along the basin. The high upward motion identified on the composite diagram above ENEB $\left(>0.0410^{-3} \mathrm{hPa} \cdot \mathrm{s}^{-1}\right)$ strengthened on an average by about $25 \%\left(0.0110^{-3} \mathrm{hPa} \cdot \mathrm{s}^{-1}\right)$ for the twelve selected events in the region where large MCS densities were mostly observed.

Analogous to the zonal wind (Figure 9) and vertical velocity (Figure 10) analyses, altitude-longitude composite diagrams of the specific humidity (in $\mathrm{g} \cdot \mathrm{kg}^{-1}$ ) are presented for an average of the same twelve selected events (Figure 11). The composite pattern (Figure 11(a)) shows a moistened atmosphere with values higher than $12 \mathrm{~g} \cdot \mathrm{kg}^{-1}$ within the lower layers (900-1000 hPa) all along the basin. While the vertical specific humidity stratification was quite stable in the open ocean, the composite pattern of Figure 11(a) indicates a similar slow increasing of that variable in the whole atmospheric column close to the two continents., The 12event composite anomaly pattern (Figure 11(b)) shows a moisture deficit $\left(\sim-0.2 \mathrm{~g} \cdot \mathrm{kg}^{-1}\right)$ close to the African continent and an excess of moisture (up to $+0.6 \mathrm{~g} \cdot \mathrm{kg}^{-1}$ ) throughout the whole vertical atmospheric column above in the vicinity of ENEB.

To further investigate the moisture exchange process that developed at the sea surface during the selected events, we calculated the LH flux composites in a manner different from that used for the last three parameters. The analysis was performed inside the same region $2.5^{\circ} \mathrm{S}-12.5^{\circ} \mathrm{S} ; 40^{\circ} \mathrm{W}-20^{\circ} \mathrm{E}$. The top panels of Figure 12 show the 12-event-composite latitude-longitude LH patterns that were computed for the days of EW onsets (Figure 12(a)) and the days (or first days) of the selected strong rainfall episodes observed over ENEB 


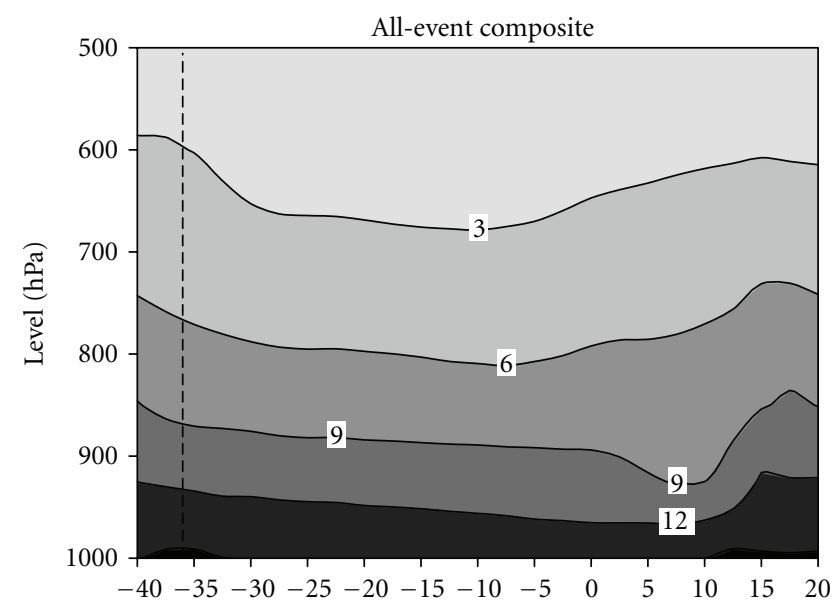

(a)

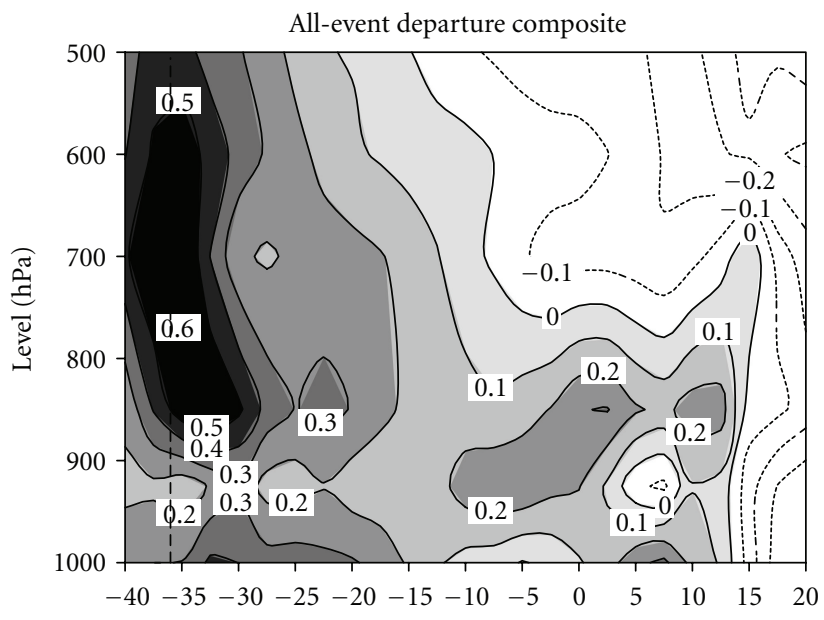

(b)

FIgURE 11: Same as Figure 8 but for the specific humidity $\left(\mathrm{g} \cdot \mathrm{kg}^{-1}\right)$. Positive values are shaded.

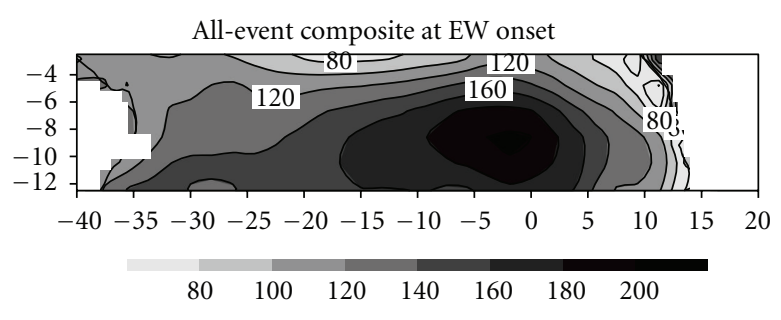

(a)

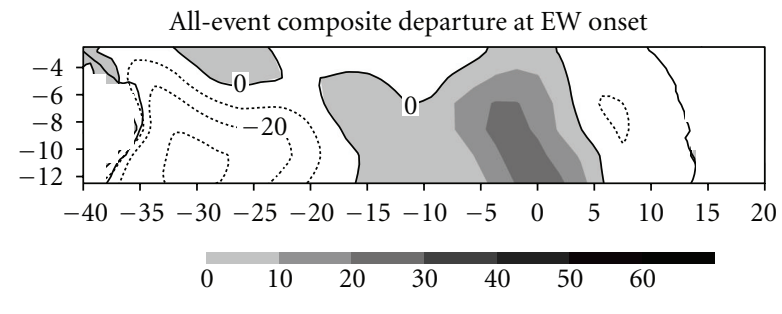

(c)

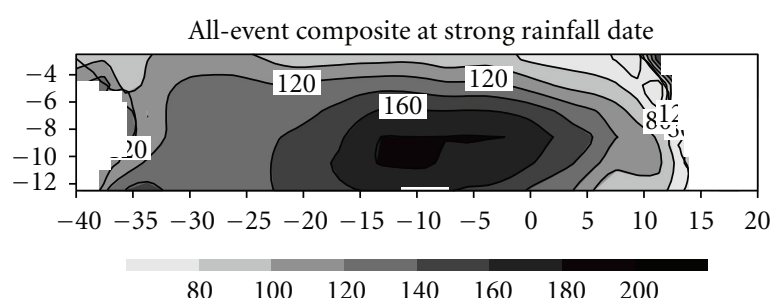

(b)

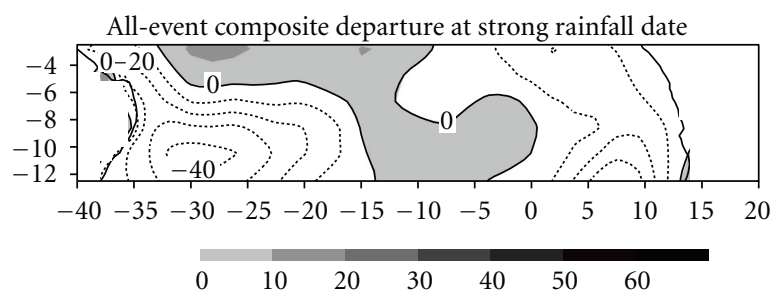

(d)

Figure 12: Latitude-longitude composite values ((a), (b)) and composite anomalies ((c), (d)) of LH flux (W· $\left.{ }^{-2}\right)$ during the onset of EWs $((\mathrm{a}),(\mathrm{c}))$ and during the day (or first day) of strong rainfall anomaly ((b), (d)) over ENEB. Positive values (energy lost by ocean evaporation) are shaded.

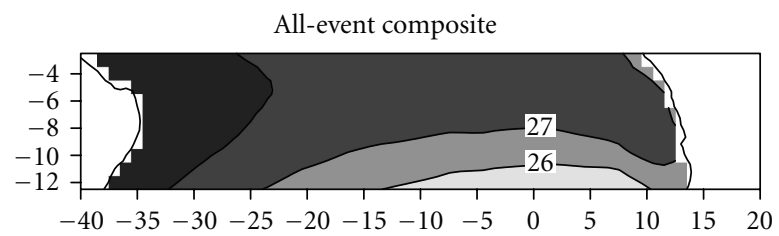

(a)

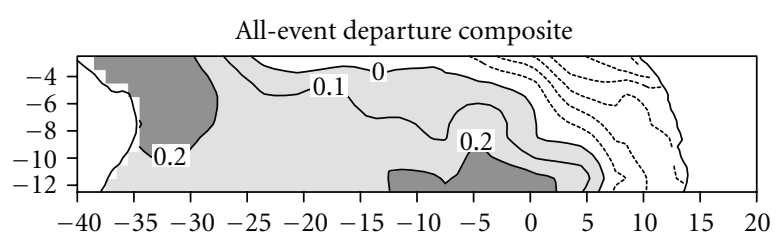

(b)

FIGURE 13: Latitude-longitude composite values (a) and composite anomalies (b) of SST $\left({ }^{\circ} \mathrm{C}\right)$ averaged during the periods of the twelve selected events from the onset of EWs until the day (or first day) of strong-rainfall anomaly episodes over ENEB. Positive values are shaded. 


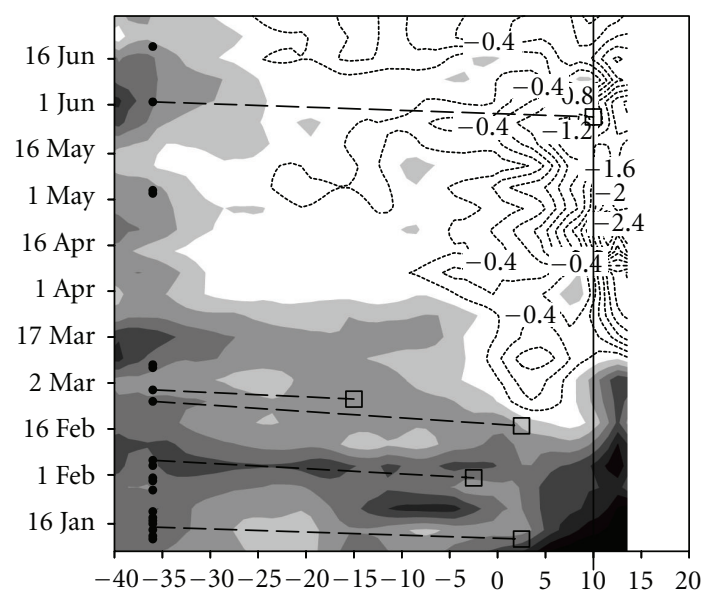

(a)

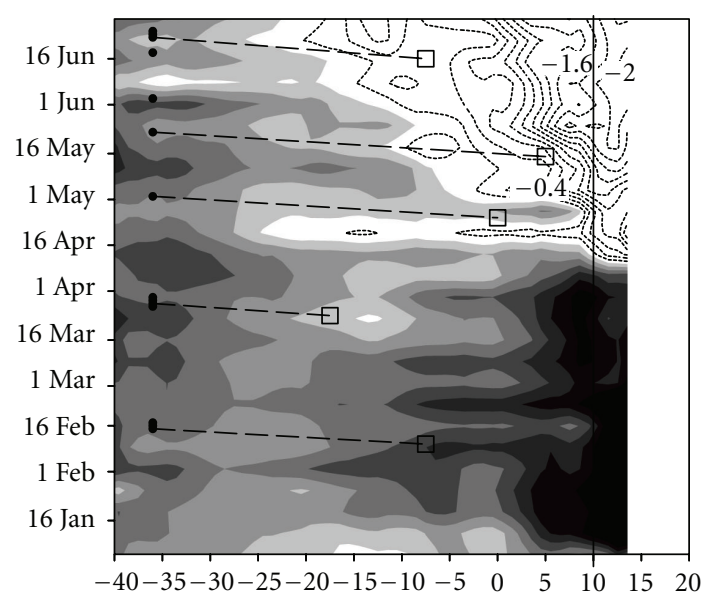

(b)

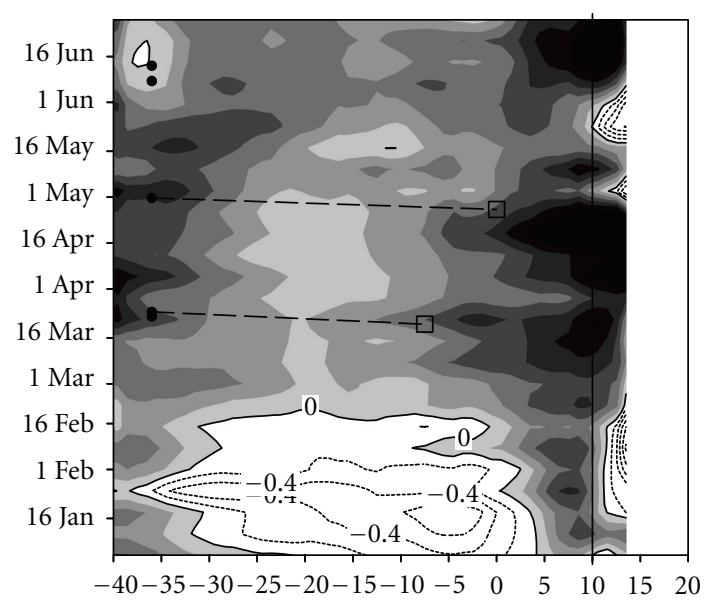

(c)

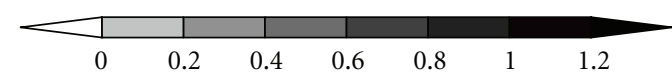

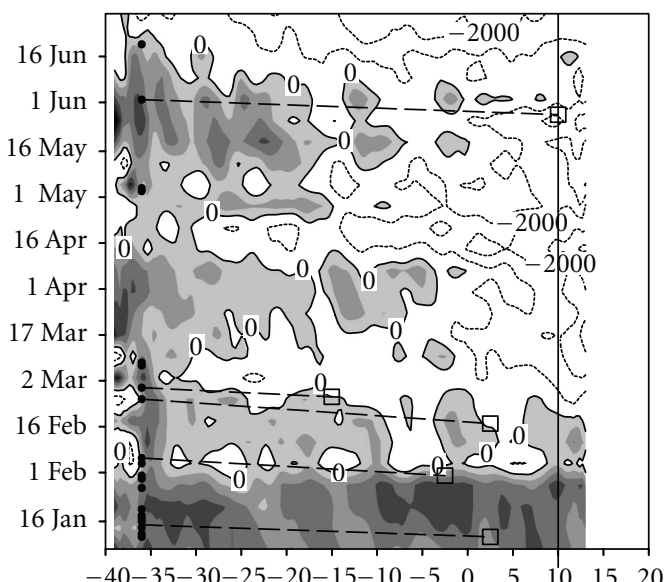

(d)

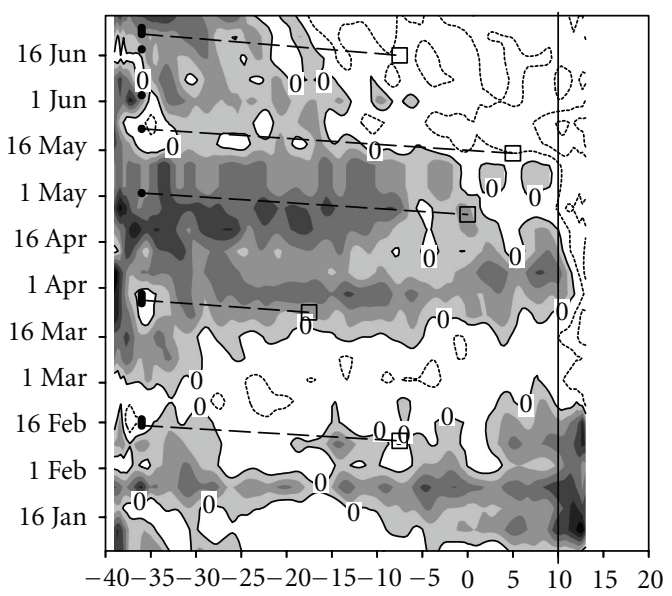

(e)

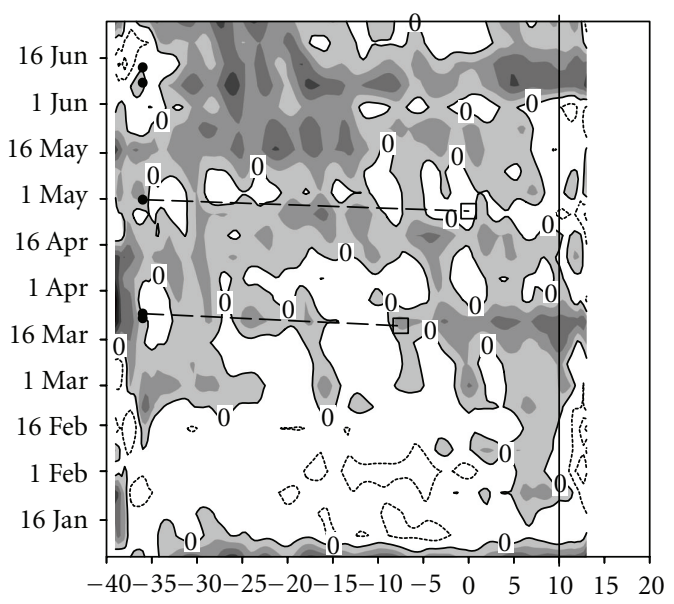

(f)

Figure 14: Time-longitude SST anomaly ((a), (b), (c)) $\left({ }^{\circ} \mathrm{C}\right)$ and $\mathrm{HC}$ anomaly ((d), (e), (f)) $\left(\mathrm{KJ} \cdot \mathrm{cm}^{-2}\right)$ averaged over $2.5^{\circ} \mathrm{S}-12.5^{\circ} \mathrm{S}$ for the periods January-June of 2004 (top), 2005 (middle), and 2006 (bottom). Positive values are shaded. The horizontal signatures of the twelve selected EW events are shown by dashed lines. 
(Figure $12(\mathrm{~b})$ ). Positive $\mathrm{LH}$ values (from 80 to $180 \mathrm{~W} \cdot \mathrm{m}^{-2}$ ), related to energy loss by evaporation from the ocean to the atmosphere, were noted in the whole study domain. The LH maximum $\left(>180 \mathrm{~W} \cdot \mathrm{m}^{-2}\right)$ occurred within the longitudes $10^{\circ} \mathrm{W}-3^{\circ} \mathrm{E}$ at the onset of the EW 12-event composite (Figure 12(a)) and then slightly decreased and displaced westward up to $13^{\circ} \mathrm{W}-8^{\circ} \mathrm{W}$ until the day (or first day) of the strong rainfall 12-episode composite (Figure 12(b)). The region of $\mathrm{LH}$ maximum was practically the same region as that one which was already identified for the intensification of the trades (see Figure 9(b)). It also coincided with the region where the SST was greater than $27^{\circ} \mathrm{C}$ (see Figure $13(\mathrm{a})$ ). The bottom panels of Figure 12 show the LH 12-event-composite departures. On average, excess evaporation was noted at the EW 12-onset composite (Figure 12(c)) in the mideastern basin (east of $20^{\circ} \mathrm{W}$ ), with a maximum departure of up to $50 \mathrm{~W} \cdot \mathrm{m}^{-2}$ centered within $10^{\circ} \mathrm{S}-2^{\circ} \mathrm{W}$. Conversely, the negative $\mathrm{LH}$ anomaly $\left(<-10 \mathrm{~W} \cdot \mathrm{m}^{-2}\right)$ in the western basin (west of $20^{\circ} \mathrm{W}$, i.e., where the SST is generally $>28^{\circ} \mathrm{C}$; see Figure 13(a)) indicated a simultaneous, moderate deceleration of evaporation. The evaporation deceleration intensified in the vicinity of the ENEB coast $\left(<-20 \mathrm{~W} \cdot \mathrm{m}^{-2}\right)$ within the day (or the first day) of the strong rainfall 12-episode composite (Figure 12(d)). Concurrently, the high evaporation excess observed in the mideastern basin decreased drastically in amplitude and extension but remained strongly positive $\left(\sim 30 \mathrm{~W} \cdot \mathrm{m}^{-2}\right)$.

As a summary of the above results, the atmospheric composite behavior averaged during the twelve selected events can be interpreted as follows. An excess of evaporation occurred in the mideastern region of the south-equatorial Atlantic basin. This excess of moisture was transported westward by the stronger-than-normal trades. Additionally, an active EW synoptic system was present in the region triggering convection and helping the convection organization in the mesoscale system. The resultant moisture accumulation in the western basin fed the MCSs over the ENEB, which led to strong rainfall episodes and, in turn, reduced evaporation in the western south-equatorial basin. These changes in the ocean-atmosphere interaction process were consistent with similar scenarios previously analyzed at the global scale [35] and in the equatorial Pacific [36-39].

4.2. Oceanic Thermal Conditions. We investigated the thermal conditions of the surface and subsurface ocean that occurred inside the oceanic studied region during the twelve selected events. Figure 13 shows the 12-event-composite and the 12-event-composite anomaly latitude-longitude patterns derived from the weekly SST 1997-2006 climatology of Reynolds et al. [31]. High values of SST $\left(>25^{\circ} \mathrm{C}\right)$ were observed in the entire southern-equatorial basin (Figure $13(\mathrm{a}))$, with the highest SST $\left(>28^{\circ} \mathrm{C}\right)$ in the vicinity of ENEB. The SST composite anomaly (Figure 13(b)) shows limited ocean cooling $\left(<-0.2^{\circ} \mathrm{C}\right)$ close to the African coast north of $7^{\circ} \mathrm{S}$, whereas positive SST departure $\left(>+0.1^{\circ} \mathrm{C}\right)$ was noticed off African coast south of $7^{\circ} \mathrm{S}$ throughout the entire midwestern basin and especially in the vicinity of ENEB where the warming reached $+0.2^{\circ} \mathrm{C}$. A similar inverse relationship between warming SST and decreasing LH (see Figures 12(c), 12(d)) has been observed in the tropicalwestern Pacific [35-38] when the lower atmosphere becomes more convectively unstable.

Figure 14 shows the weekly SST and HC departures along $40^{\circ} \mathrm{W}-20^{\circ} \mathrm{E}$, averaged into $2.5^{\circ} \mathrm{S}-12.5^{\circ} \mathrm{S}$ during each first semester of 2004 (top), 2005 (middle), and 2006 (bottom). The dashed lines represent the trajectories of the twelve selected EWs. Generally, SST and HC anomalies were strongly positive $\left(\mathrm{SSTa}>0.4^{\circ} \mathrm{C} ; \mathrm{HCa}>1000 \mathrm{KJ} \cdot \mathrm{cm}^{-2}\right.$ ) during long periods that included the selected events. This is especially true for the first four events of 2004 (between January and March), the three events April to May 2005 and the two events of 2006; however, positive SST and HC anomalies were not as clear for the remaining events, such as the June 2004 event. Because the ocean climate lowfrequency variability (especially in the subsurface) is much different from the short-frequency variability of the atmospheric circulation, it is not surprising that the ocean thermal anomaly pattern does not perfectly match the atmospheric time scale of the selected events. Independent studies (J. Servain, pers. comm.) that used the observed 0-300 $\mathrm{m} \mathrm{HC}$ from the Prediction and Research Moored Array in the Tropical Atlantic (PIRATA) array in the tropical Atlantic [40, 41] during the same years are in complete agreement with the present $\mathrm{HC}$ results.

\section{Conclusion}

This study details a relationship between westward positive unfiltered relative vorticity over the southern tropical Atlantic, MCS occurrences over the western southern tropical Atlantic, and strong rainfall events (anomaly > $10 \mathrm{~mm} \cdot \mathrm{day}^{-1}$ ) over the ENEB. The results show evidence of oceanic-atmospheric processes responsible for these strong precipitation episodes. These processes, named here "true alarms", include a combination of atmospheric variables initially based on EWs/positive vorticity anomalies which initiate at east of $20^{\circ} \mathrm{W}$ and propagate westwards with a mean velocity of about $8 \mathrm{~m} \cdot \mathrm{s}^{-1}$ reaching the eastern longitude of ENEB in a few days. When approaching the American continent, they are associated with westward MCS development that, in turn, induces strong rainfall events over ENEB. A series of twelve strong rainfall episodes selected during a testing period of three years (2004-2005-2006) contributed to a significant amount of precipitation over the ENEB, able to reaching up to $70 \%$ of the daily occurrences and $60 \%$ of the total monthly rainfall amount.

A composite analysis averaging atmospheric and oceanic conditions over the south-equatorial Atlantic basin during the twelve selected events allowed for the reconstruction of the mean climatic scenario that could be strongly responsible for these rainfall episodes over ENEB. This scenario, associated with intensification of the easterly trades and increasing of the vertical dynamic instability, leads to formation of EWs [42] in the mideastern part of the southequatorial basin. During this specific event, the ocean lost an excess of latent heat by evaporation. The resultant westward advection of that excess of moisture reaches the American 
continent. Upward motion and excess specific humidity in the troposphere within the western region can then increase the organized deep convection $[43,44]$, thus favoring strong rainfall episodes over ENEB [45]. As a collateral effect explained by this regional convection [37], the latent heat flux diminishes in the western-subequatorial basin, where SST is especially high.

Atmospheric scenarios such as the one described above seem to develop during positive SST anomaly episodes in the south-equatorial Atlantic basin from Africa to America. High SST affects the air temperature and the moisture properties in the atmospheric boundary layer through turbulent fluxes above the sea surface [46-48]. Furthermore, such episodes occur generally during a low frequency powerful warming within the subsurface oceanic mixing layer. When combined with an active synoptic EW, our study suggests that lowfrequency higher than normal heat content in the upper layer of the south-equatorial Atlantic can be favorable to control hydrodynamic mechanisms leading to strong rainfall occurrences over ENEB.

Ocean-atmosphere processes that can be monitored in real-time (e.g., from satellite-observed winds and from surface and subsurface variables deduced from PIRATA) have the potential to improve the forecasting of strong precipitation episodes during the seasonal rainfall over ENEB (e.g., the last episodes that occurred in 2010, see Note 1) and thus increase our warning capacity for severe weather conditions in that region. In counterpart to future observational and diagnostic efforts, coupled-model simulations could give one useful dynamical basis for such ocean-atmosphere processes. Such initiatives are encouraged to better explain the observed phenomena. That is the focus of the program Centro de Alerta de Fenomenos Extremos (CAFE) financed by the Brazilian Financiadora de Estudos e Projetos (FINEP).

In parallel to these incoming numerical studies related to the ocean-atmospheric process analysed here and as a necessary complement to apprehend the full dynamics, further analyses are also in progress to understand why, sometimes, "false alarms" depicted by some EWs are not associated to strong rainfall events over ENEB and, symmetrically, why, sometimes, strong rainfall events over ENEB are not associated to marked EW signatures.

\section{Acknowledgments}

This work was initially performed during the French-Brazilian IRD-CNPq Project "Climate of the Tropical Atlantic and Impacts on the Northeast" (CATIN), $\mathrm{N}^{\circ}$ CNPq Process 492690/2004-9, and was concluded during the FINEP Project Centro de Alerta de Fenômenos Extremos (CAFE), $\mathrm{N}^{\circ}$ FINEP Process $01080617 / 00$. Y. K. Kouadi stayed in 2007 at the Fundação Cearense de Meteorologia e Recursos Hídricos (FUNCEME) and was supported by the French Institut de Recherche pour le Développement (IRD) grant (2006-2007). J. Servain would like to thank FUNCAP for the financial support (grant no. BPV-0025-00055.01.00/11). C. A. D. Lentini would like to thank $\mathrm{CNPq}$ for the financial support (grants nos. 478480/2009-1 and 478398/2006-9). The in situ rainfall data over ENEB were obtained from meteorological institutes of the Brazilian States of Alagoas, Bahia, Ceará, Paraiba, Pernambuco, Rio Grande do Norte, and Sergipe. Thanks to W. Z. Arruda for his participation in the HC computation and to Ed Sarachik and Mike McPhaden for their valuable comments and advices.

\section{References}

[1] S. Hastenrath, "Prediction of Northeast Brazil rainfall anomalies," Journal of Climate, vol. 3, pp. 893-904, 1993.

[2] C. G. Markham and D. R. Mclain, "Sea surface temperature related to rain in Ceará, north-eastern Brazil," Nature, vol. 265, no. 5592, pp. 320-323, 1977.

[3] S. Hastenrath and L. Heller, "Dynamics of climatic hazards in Northeast Brazil," Quaternary Journal of Royal Meteorological Society, vol. 103, pp. 77-92, 1977.

[4] A. D. Moura and J. Shukla, "On the dynamics of droughts in northeast Brazil: observations, theory and numerical experiments with a general circulation model," Journal of the Atmospheric Sciences, vol. 38, no. 12, pp. 2653-2675, 1981.

[5] S. Hastenrath and L. Greischar, "Further work on the prediction of northeast Brazil rainfall anomalies," Journal of Climate, vol. 6, no. 4, pp. 743-758, 1993.

[6] V. B. Rao, I. F. A. Cavalcanti, and K. Hada, "Annual variation of rainfall over Brazil and water vapor characteristics over South America," Journal of Geophysical Research D, vol. 101, no. 21, pp. 26539-26551, 1996.

[7] P. Nobre and J. Shukla, "Variations of sea surface temperature, wind stress, and rainfall over the tropical Atlantic and South America," Journal of Climate, vol. 9, no. 10, pp. 2464-2479, 1996.

[8] V. E. Kousky and N. J. Ferreira, "Interdiurnal surface pressure variations in Brazil: their spatial distributions, origins and effects," Monthly Weather Review, vol. 109, no. 9, pp. 19992008, 1981.

[9] A. Diedhiou, S. Janicot, A. Viltard, and P. Felice, "Evidence of two regimes of easterly waves over West Africa and the tropical Atlantic," Geophysical Research Letters, vol. 25, no. 15, pp. 2805-2808, 1998.

[10] A. Diedhiou, S. Janicot, A. Viltard, P. Felice, and H. Laurent, "Easterly wave regimes and associated convection over West Africa and tropical Atlantic: results from the NCEP/NCAR and ECMWF reanalyses," Climate Dynamics, vol. 15, no. 11, pp. 795-822, 1999.

[11] A. Diedhiou, L. A. T. Machado, and H. Laurent, "Mean kinematic characteristics of synoptic easterly disturbances over the Atlantic," Advances in Atmospheric Sciences, vol. 27, pp. 483-499, 2010.

[12] L. A. T. Machado, R. L. Guedes, and M. A. S. Alves, "Structural characteristics of convective systems and forcing of convection in South America observed by satellites (Características Estruturais de Sistemas Convectivos e Forçantes da convecção na América do Sul observados por satélites)," Edição Comemorativa dos dez anos do Climanálise, pp. 110-122, 1997.

[13] H. Laurent, L. A. T. Machado, C. A. Morales, and L. Durieux, "Characteristics of the Amazonian mesoscale convective systems observed from satellite and radar during the WETAMC/LBA experiment," Journal of Geophysical Research $D$, vol. 107, no. 8054, 17 pages, 2002.

[14] B. A. Hall, "Westward-moving disturbances in the South Atlantic coinciding with heavy rainfall events at Ascension Island," Meteorological Magazine, vol. 118, no. 1405, pp. 175181, 1989. 
[15] R. R. Torres and N. J. Ferreira, "Case studies of easterly wave disturbances over Northeast Brazil using the Eta Model," Weather and Forecasting, vol. 26, no. 2, pp. 225-235, 2011.

[16] Y. Yamazaki and V. B. Rao, "Tropical cloudiness over South Atlantic Ocean," Journal of the Meteorological Society of Japan, vol. 55, pp. 204-207, 1977.

[17] B. Liebmann, G. N. Kiladis, D. Allured et al., "Mechanisms associated with large daily rainfall events in Northeast Brazil," Journal of Climate, vol. 24, no. 2, pp. 376-396, 2011.

[18] G. J. Huffman, R. F. Adler, P. Arkin et al., "The Global Precipitation Climatology Project (GPCP) combined precipitation dataset," Bulletin of the American Meteorological Society, vol. 78, no. 1, pp. 5-20, 1997.

[19] R. A. Houze Jr., "Structure and dynamics of a tropical squallline system," Monthly Weather Review, vol. 105, pp. 1540$1567,1977$.

[20] I. Velasco and J. M. Fritsch, "Mesoscale convective complexes in the Americas," Journal of Geophysical Research, vol. 92, no. 8, pp. 9591-9613, 1987.

[21] V. Mathon, H. Laurent, and T. Lebel, "Mesoscale convective system rainfall in the Sahel," Journal of Applied Meteorology, vol. 41, no. 11, pp. 1081-1092, 2002.

[22] D. A. Vila, L. A. T. Machado, H. Laurent, and I. Velasco, "Forecast and tracking the evolution of cloud clusters (ForTraCC) using satellite infrared imagery: methodology and validation," Weather and Forecasting, vol. 23, no. 2, pp. 233-245, 2008.

[23] L. A. T. Machado and W. B. Rossow, "Structural characteristics and radiative properties of tropical cloud clusters," Monthly Weather Review, vol. 121, pp. 3234-3260, 1993.

[24] L. A. T. Machado, J.-P. Duvel, and M. Desbois, "Diurnal variations and modulation by easterly waves of the size distribution of convective cloud clusters over West Africa and the Atlantic Ocean," Monthly Weather Review, vol. 121, no. 1, pp. 37-49, 1993.

[25] L. A. T. Machado, W. B. Rossow, R. L. Guedes, and A. W. Walker, "Life cycle variations of mesoscale convective systems over the Americas," Monthly Weather Review, vol. 126, no. 6, pp. 1630-1654, 1998.

[26] V. Mathon and H. Laurent, "Life cycle of Sahelian mesoscale convective cloud systems," Quarterly Journal of the Royal Meteorological Society, vol. 127, no. 572, pp. 377-406, 2001.

[27] L. A. T. Machado and H. Laurent, "The convective system area expansion over Amazonia and its relationships with convective system life duration and high-level wind divergence," Monthly Weather Review, vol. 132, no. 3, pp. 714-725, 2004.

[28] K. Y. Kouadio, L. A. T. Machado, and J. Servain, Tropical atlantic hurricanes, easterly waves, and West African mesoscale convective systems, vol. 2010, Article ID 284503, 13 pages, 2010.

[29] J. Molinari, D. Vollaro, S. Skubis, and M. Dickinson, "Origins and mechanisms of eastern Pacific tropical cyclogenesis: a case study," Monthly Weather Review, vol. 128, no. 1, pp. 125-139, 2000.

[30] E. Kalnay, M. Kanamitsu, R. Kistler et al., "The NCEP/NCAR 40-year reanalysis project," Bulletin of the American Meteorological Society, vol. 77, no. 3, pp. 437-471, 1996.

[31] R. W. Reynolds, N. A. Rayner, T. M. Smith, D. C. Stokes, and W. Wang, "An improved in situ and satellite SST analysis for climate," Journal of Climate, vol. 15, no. 13, pp. 1609-1625, 2002.

[32] W. Z. Arruda, C. A. D. Lentini, and E. J. D. Campos, "The use of satellite-derived upper layer heat content to study the climate variability in the South Atlantic," Brazilian Journal of Cartography, vol. 57, pp. 87-92, 2005.
[33] W. Z. Arruda and C. A. D. Lentini, "A remote sensing derived upper ocean heat content dataset for the equatorial atlantic: Comparison with PIRATA project data," Revista Brasileira de Geofísica, vol. 29, no. 1, pp. 43-56, 2011.

[34] D. L. Bartels and R. A. Maddox, "Midlevel cyclonic vortices generated by mesoscale convective systems," Monthly Weather Review, vol. 119, no. 1, pp. 104-118, 1991.

[35] L. Yu, "Global variations in oceanic evaporation (1958-2005): the role of the changing wind speed," Journal of Climate, vol. 20, no. 21, pp. 5376-5390, 2007.

[36] B. C. Weare, P. T. Strub, and M. D. Samuel, "Annual mean heat fluxes in the tropical Pacific Ocean," Journal of Physical Oceanography, vol. 11, pp. 705-717, 1981.

[37] G. J. Zhang and M. J. McPhaden, "The relationship between sea surface temperature and latent heat flux in the equatorial Pacific," Journal of Climate, vol. 8, no. 3, pp. 589-605, 1995.

[38] G. J. Zhang, V. Ramanathan, and M. J. McPhaden, "Convection-evaporation feedback in the Equatorial Pacific," Journal of Climate, vol. 8, pp. 3040-3051, 1995.

[39] A. H. Sobel, "On the coexistence of an evapration minimum and precipitation maximum in the warm pool," Journal of Climate, vol. 16, pp. 1003-1009, 2003.

[40] J. Servain, A. J. Busalacchi, M. J. McPhaden et al., "A pilot research moored array in the tropical atlantic (PIRATA)," Bulletin of the American Meteorological Society, vol. 79, no. 10, pp. 2019-2031, 1998.

[41] B. Bourlès, R. Lumpkin, M. J. McPhaden et al., "The Pirata Program: history, accomplishments, and future directions," Bulletin of the American Meteorological Society, vol. 89, no. 8, pp. 1111-1125, 2008.

[42] J. G. Charney and M. Stern, "On the stability on internal baroclinic jets in rotating atmosphere," Journal of Atmospheric Sciences, vol. 19, pp. 159-172, 1962.

[43] R. Rotunno and K. A. Emanuel, "An air-sea interaction theory for tropical cyclones. Part II: evolutionary study using a nonhydrostatic axisymmetric numerical model," Journal of the Atmospheric Sciences, vol. 44, no. 3, pp. 542-561, 1987.

[44] W.-K. Tao, J. Simpson, and S.-T. Soong, "Numerical simulation of a subtropical squall line over the Taiwan Strait," Monthly Weather Review, vol. 119, no. 11, pp. 2699-2723, 1991.

[45] K. L. Brubaker, D. Entekhabi, and P. S. Eagleson, "Estimation of continental precipitation recycling," Journal of Climate, vol. 6, no. 6, pp. 1077-1089, 1993.

[46] N. E. Graham and T. P. Barnett, "Sea surface temperature, surface wind divergence, and convection over tropical oceans," Science, vol. 238, no. 4827, pp. 657-659, 1987.

[47] C. Zhang, "Large-scale variability of atmospheric deep convection in relation to sea surface temperature in the tropics," Journal of Climate, vol. 6, no. 10, pp. 1898-1913, 1993.

[48] A. Arking and D. Ziskin, "Relationship between clouds and sea surface temperatures in the western tropical Pacific," Journal of Climate, vol. 7, no. 6, pp. 988-1000, 1994. 

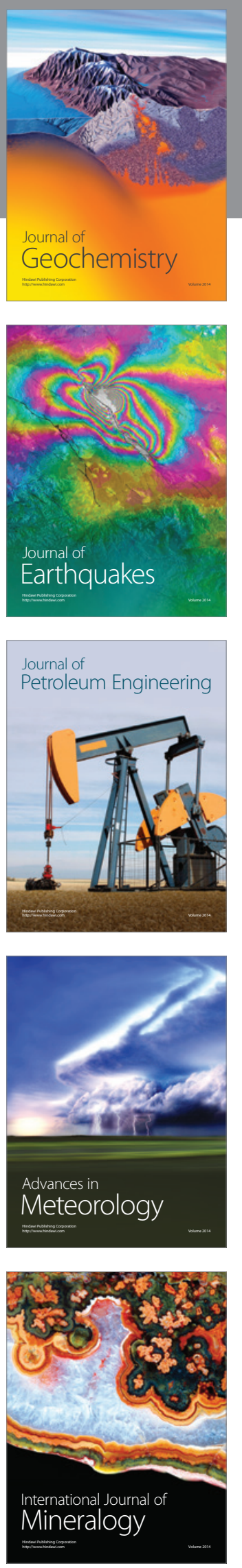
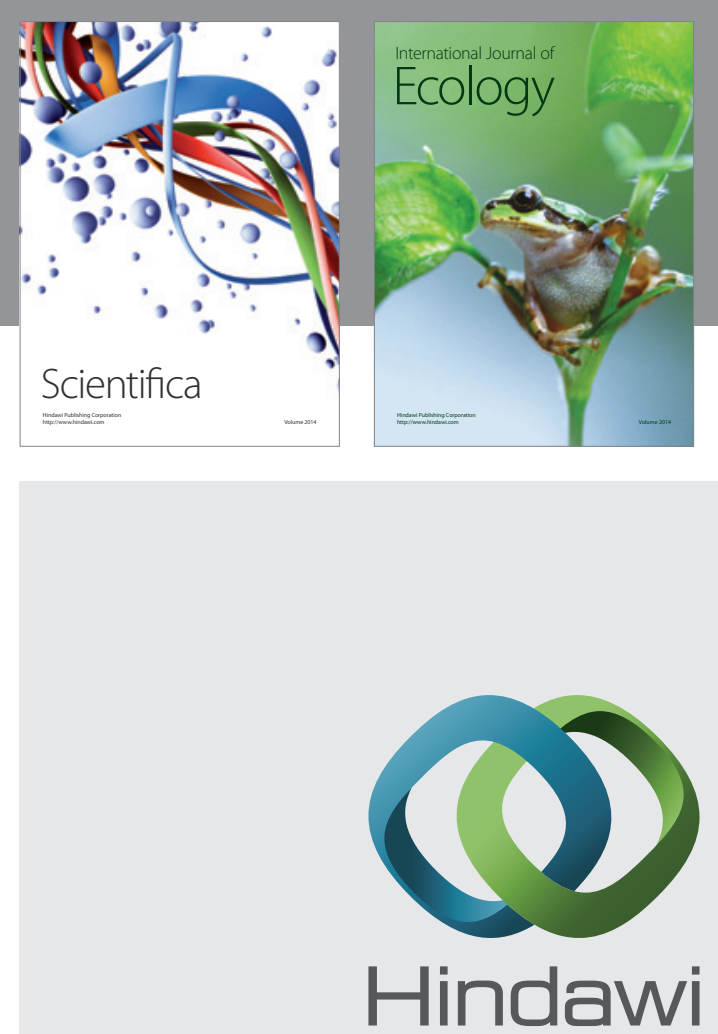

Submit your manuscripts at http://www.hindawi.com
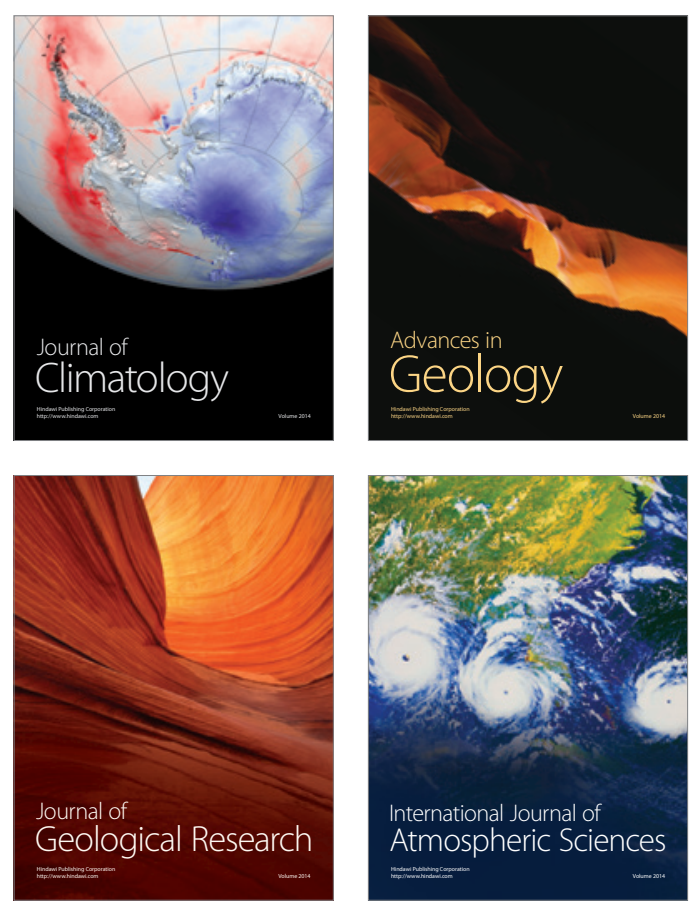
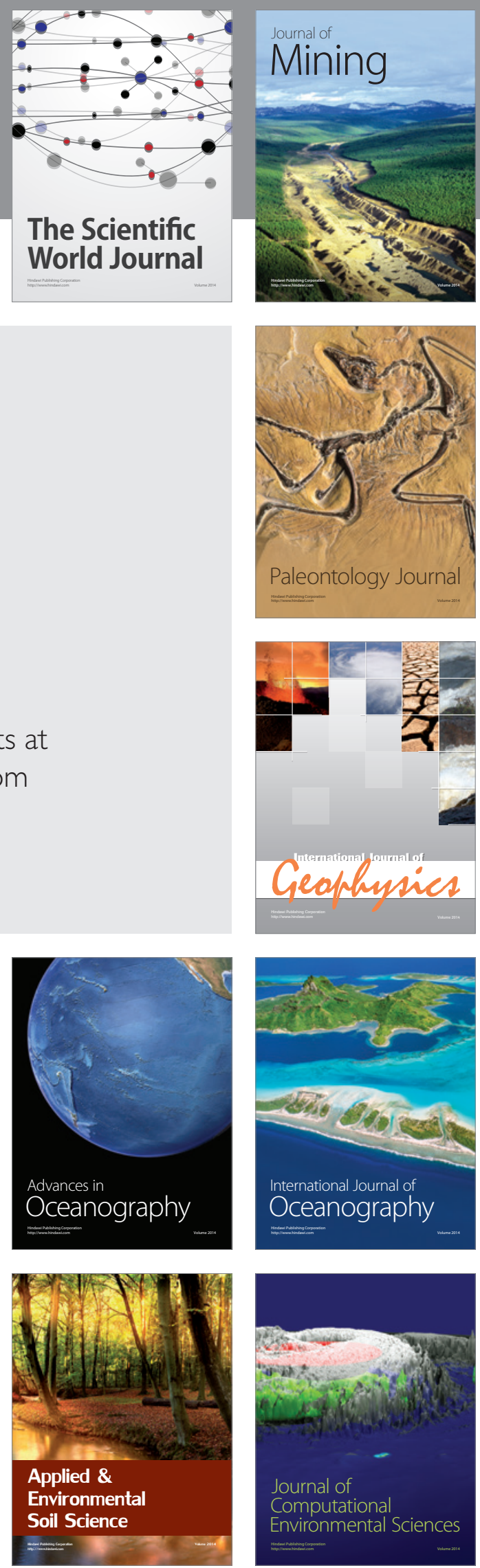